\title{
Urban Integration of Green Roofs: Current Challenges and Perspectives
}

\author{
Mitali Yeshwant Joshi *(D) and Jacques Teller (iD \\ Local Environment Management and Analysis (LEMA), Urban and Environmental Engineering Department, \\ University of Liège, 4000 Liège, Belgium; Jacques.teller@uliege.be \\ * Correspondence: mjoshi@uliege.be
}

Citation: Joshi, M.Y.; Teller, J. Urban Integration of Green Roofs: Current Challenges and Perspectives. Sustainability 2021, 13, 12378. https://doi.org/10.3390/su132212378

Academic Editors: Domenico Mazzeo and Antonio Caggiano

Received: 20 September 2021 Accepted: 3 November 2021 Published: 9 November 2021

Publisher's Note: MDPI stays neutral with regard to jurisdictional claims in published maps and institutional affiliations.

Copyright: (c) 2021 by the authors. Licensee MDPI, Basel, Switzerland. This article is an open access article distributed under the terms and conditions of the Creative Commons Attribution (CC BY) license (https:// creativecommons.org/licenses/by/ $4.0 /)$.

\begin{abstract}
Green roofs (GRs) are a sustainable alternative to conventional roofs that provide multiple ecosystem services. Integrating GRs into urban areas is highly relevant considering the rapidly increasing built-up in cities. Therefore, this paper systematically and comprehensively reviews the recent literature from 2011 to 2019 on GRs to identify the challenges and perspectives related to the urban integration of GRs. The review suggests that the effectiveness of GRs in delivering ecosystem services is largely dependent on context-specific parameters such as weather conditions and existing construction or design-related parameters. Integrating GRs into urban areas can be challenging given the diversity of actors, functions, and conditions characterizing these areas. Although significant research has already been conducted on GRs, research covering more geographical locations and contexts is needed. The review points out the need to include future urbanization scenarios, such as tall buildings while analyzing the impact of GRs on ecological networks. Additionally, the review emphasizes the inclusion of urban morphological parameters alongside an analysis of the impact of GRs on microclimate regulation and air quality. In terms of social acceptance, this review points out the need to consider the temporal cycles of vegetation for noting users' perspectives. Additionally, further research is required on the social impact of GRs, considering their influence on property prices. Lastly, the review stresses the need for more city-scale studies on the impact of GRs on ecosystem services.
\end{abstract}

Keywords: green roofs; cities; ecosystem services; feasibility; social acceptance

\section{Introduction}

Unprecedented urbanization in the world has given rise to enormous challenges associated with energy consumption, social inequality, air and water pollution, and resource depletion resulting in a massive strain on urban systems [1]. The United Nations (UN) has estimated that around one-third of the world's population will live in the cities by 2050 [2]. Thus, it is essential to significantly transform the way urban spaces are built and managed to ensure the sustainable development of cities [3].

At present, urban ecosystems consist of a large proportion of built infrastructure along with high population densities [4,5]. Urban ecosystems experience the urban heat island (UHI) effect, air and water pollution, and frequent flooding, owing to the lack of green spaces [6-8]. Impervious surfaces such as building roofs are abundant within urban ecosystems, occupying around $20-25 \%$ of urban surfaces. These are located on buildings that consume a significant amount of energy and are responsible for substantial greenhouse gas (GHG) emissions [9]. Given this background, nature-based solutions such as green roofs (GRs) are increasingly gaining popularity due to their positive effect on urban ecosystems [10-12].

GRs are defined as living vegetation planted on the roofs of buildings [13,14]. GRs can improve the energy performance of the buildings and aid in combating the UHI effect by reducing the atmospheric temperature as well as providing human thermal comfort [15]. 
GRs also aid in stormwater management owing to their high water retention capacity [16]. Apart from the environmental benefits, GRs are also observed to be beneficial in enhancing the quality of life of urban residents [17] (See Figure 1).

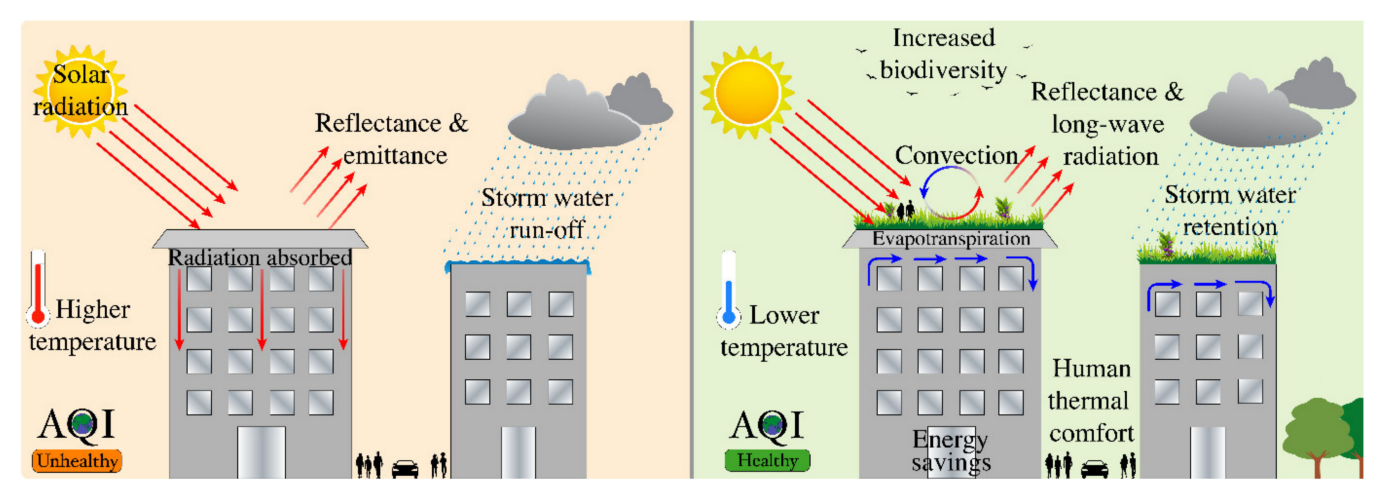

Figure 1. Schematic representing the diverse processes involved in conventional roofs and GRs (AQI-Air Quality Index).

GRs can be broadly classified into intensive and extensive GRs (IGRs and EGRs, respectively) [18] based on differences in substrate thickness, benefits, costs, maintenance levels, and vegetation type [19-21]. IGRs have a thick layer of substrate, which is the growing medium, wherein many varieties of plants can be cultivated [22]. Additional structural support is required for this type of roof due to the heavy weight of the substrate [14]. For example, urban rooftop agriculture and rooftop gardening are often categorized as IGRs $[20,23]$. In contrast, EGRs have a relatively thin layer of lightweight substrate, which needs little or no additional structural support. This type of GR requires lower maintenance, resulting in more widespread application compared to IGRs [24]. EGRs are upheld for being cost-effective in terms of installation, making the benefits affordable [18]. In recent years, researchers have designed a new type of GR, semi-intensive GRs, combining the advantages of both IGRs and EGRs [25]. Despite the differences in typologies and benefits, GRs are usually presented as sustainable and environmentally friendly [26].

Due to attractive qualities such as the sustainability and environmental friendliness of GRs, both private and public sectors are promoting their installation [27]. Many municipalities in North America, Europe, and Asia actively encourage GR installation through policy instruments such as construction regulations and economic incentives [25,28,29]. Moreover, academic research on the subject of GRs has increased exponentially in recent years [12].

In recent years, due to rapid urbanization, urban planners have been forced to tackle the challenge of sustainable and comprehensive planning of cities [30]. Urban sustainability is often connected to urban forms; for instance, a dense and compact urban form is more sustainable as compared to urban sprawl [31,32]. However, city densification has resulted in a lack of urban green spaces. Green spaces are essential in urban areas as they provide essential ecosystem services to the citizens and aid in maintaining habitats for wildlife $[33,34]$. Thus, it is vital to provide a solution to increase the green spaces in cities. This solution must also be feasible and socially acceptable to be incorporated as part of city planning. Due to the increase in built-up areas, incorporating GRs into urban areas is highly relevant, making it essential to understand the urban integration of GRs. Therefore, this paper aims to identify the challenges and perspectives related to the urban integration of GRs by reviewing the current literature on the delivery of the four ecosystem services by GRs, namely biodiversity enhancement, climate regulation, water management, and air quality improvement, along with their social acceptability and feasibility. The paper then discusses the challenges observed in the delivery of ecosystem services, perceiving the benefits of GRs and their feasibility. Lastly, it provides a perspective for future studies that are required in this context. 
The remainder of the paper is organized as follows. Section 2 discusses the methodology. Section 3 consists of an in-depth discussion on the contribution of GRs to various aspects, followed by the discussion and conclusions in Sections 4 and 5, respectively.

\section{Methodology}

There are review-based studies on GRs emphasizing either their benefits or their role in strengthening ecosystem services. A review by Berardi et al. [25] provides a comprehensive picture of the benefits of GRs and concludes that GRs have undeniable benefits. A recent review by Francis and Jensen [35] that focuses on three specific ecosystem services provided by GRs, namely UHI mitigation, air quality, and energy consumption, suggests that the evidence is inconclusive about the benefits of GRs, and they can be useful only under certain conditions. A more recent review by Shafique et al. [12] gives a general overview of GR literature. However, it is not a systematic review, and the methodology is not explicit. Furthermore, essential ecosystem services such as biodiversity enhancement, water quality management, air quality improvement, and social preferences and acceptance are not discussed in detail. Therefore, there is a need for a systematic and comprehensive review of the recent literature on GRs that discusses almost all the ecosystem services along with the aspects of social acceptability and feasibility. Thus, in this review, we adopt a methodology similar to Francis and Jensen [35].

The review includes peer-reviewed journal articles which were found by searching the SCOPUS database. The search comprised relevant synonymous terms to identify relevant literature regarding the six aspects mentioned above. The literature search constituted a combination of terms such as green roofs, city, and one of the mentioned aspects to ensure that the selection of publications was relevant to the individual aspects. To ensure a reasonable number of publications, we added proxies of the key terms in our query (Table 1). Moreover, to obtain the literature specific to the subject, the key terms were searched only in the papers' title, abstract, and keywords. The review focused only on research articles to obtain an overview of the original research done in the field of GRs.

Table 1. Search terms and their combinations.

\begin{tabular}{cc}
\hline Search Terms & Synonyms \\
\hline Green Roofs & Green Roof * OR Roof * garden OR Vegetat * roof OR Roof * greening \\
AND
\end{tabular}

We conducted this search in April 2020, restricting it to research articles written in English and published from January 2011 to December 2019. Subsequently, we filtered 
the papers by screening the titles and abstracts and eliminated those articles that did not focus on understanding the impact of GRs on the selected aspects. Additionally, to achieve a feasible number of publications for review, we only focused on papers that compare GRs with bare, impervious, and conventional roofs. Papers including other kinds of green urban infrastructure were not reviewed.

\section{Results}

This section presents the number of papers selected for review (Section 3.1) and reviews them by discussing the contribution of GRs to the six defined aspects (Section 3.2).

\subsection{Selection and Classification of Literature}

The search strategy resulted in a total of 739 papers. We read the abstracts of all 739 papers and, based on the filtering process outlined in the previous section, selected the 158 most relevant studies for a full-text review. Figure 2 provides the details of the papers obtained initially, regarding each aspect, and the number of papers selected for the review based on the selection criteria. It is evident from Figure 2 that there is a significant amount of literature available on the contribution of GRs to water management and UHI mitigation as compared to the other aspects, based on our search strategy. Additionally, we classified the studies based on their scale; for instance, at a city, neighborhood, or building/prototype level (Figure 3). Most studies were observed to have been carried out at a prototype or single-building scale. However, aspects such as water management, UHI, and feasibility consist of a few studies which were carried out at city and neighborhood scales. For the aspects of air quality and biodiversity, most studies were experimental and carried out on specific buildings or prototypes. In the case of social acceptance, the studies discuss the opinions of various stakeholders; therefore, the scale of the study was not relevant.

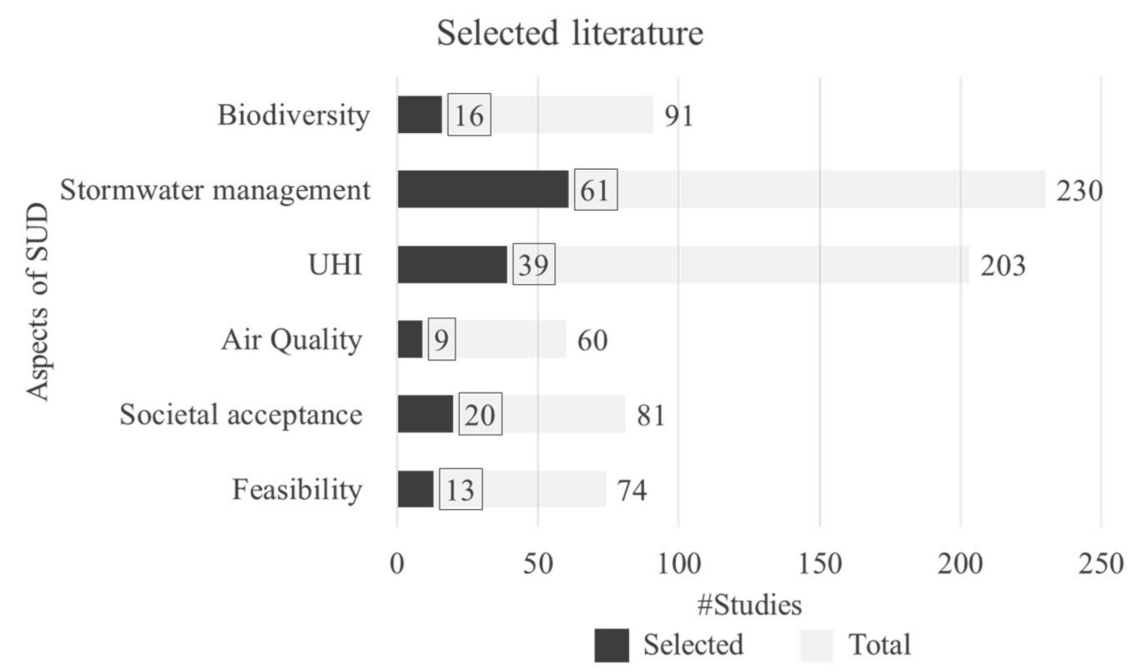

Figure 2. Schematic representing total search results and the number of studies selected for fulltext review.

\subsection{GR's Impact on Various Ecosystem Services}

\subsubsection{Biodiversity}

Studies show that GRs support various types of flora, such as herbaceous perennials, succulents, indigenous species, wildflower species, and fauna such as birds, butterflies, and arthropods (Table 2). Species such as ground beetles, collembolan communities, spiders, tree bugs, and hymenopterans are also found in abundance (Table 2). Mosquitoes are one of the species of arthropods, which can be harmful, as they are the carriers of severe diseases. Wong and Jim [36] reported that the mosquitoes' presence on GRs was less than in other green spaces; however, it was greater than on a bare roof. Other than arthropods, GRs have been observed to provide habitats for resident birds such as tree sparrows, spotted doves, 
and migrant birds [37-40]. These birds are attracted to GRs because of the availability of their diet, such as insects, grains, and berries [38,39].

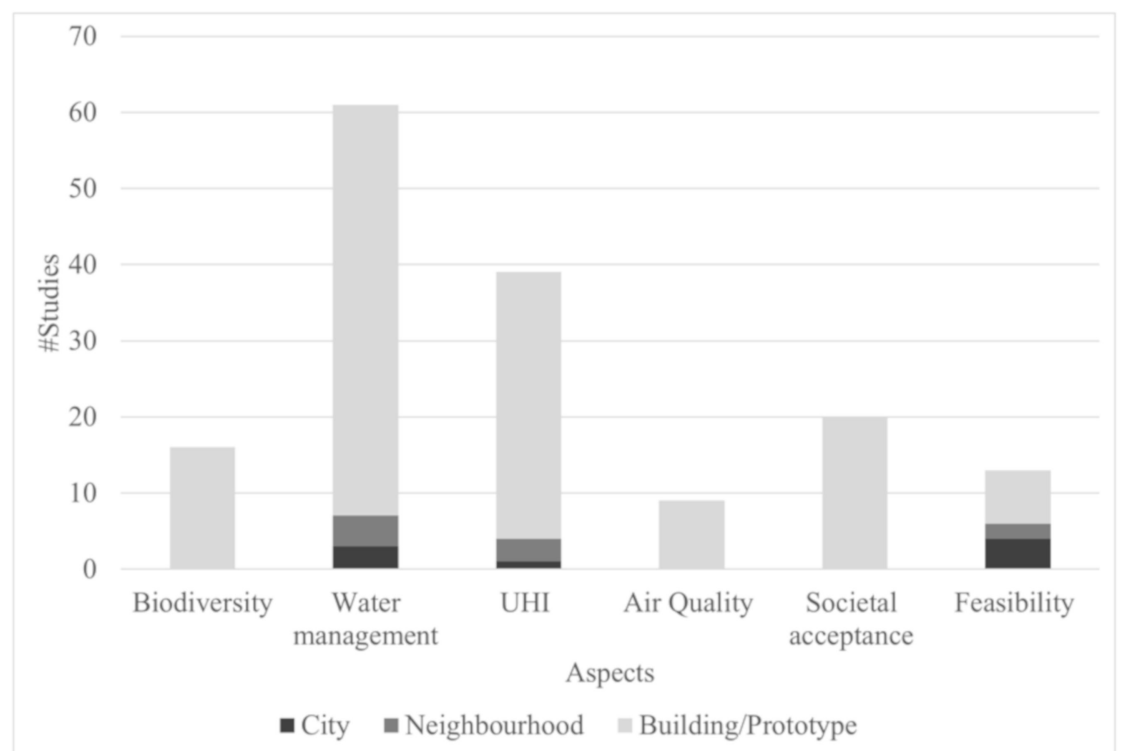

Figure 3. Classification of studies based on the scale at which they were carried out.

With regards to flora, GRs provide space for conserving indigenous species. Sedums are often planted on GRs owing to their shallow root systems and high water-use efficiency, enabling them to withstand extreme weather conditions and the limited substrate depths of EGRs [41]. However, Vandegrift et al. [42] observed that some indigenous herbaceous perennials lasted as long on GRs as common sedum species. GRs also enable the enhancement of genetically diverse plant species that facilitate the spotting of birds [41]. Moreover, GRs support wild plants and flowers, which serve as a part of the food chain for essential pollinators such as wild bees along with enhancing aesthetic appearance.

IGRs are reported to provide a medium for conserving species [43]. Furthermore, it is worth noting that most of these species are observed in large numbers only on IGRs [44,45]. EGRs also have the potential to enhance biodiversity; however, this effect is lesser compared to IGRs [46]. Apart from this, the height of the building and size of the GR [40] also act as determining factors for the enhancement of flora and fauna. Additionally, Joimel et al. [47] argue that GRs can act as a medium for connecting various urban green areas, thereby providing the potential for habitat connectivity and maintenance of the ecological network.

Table 2. Studies and discussed species supported by GRs along with the suitable conditions for their enhancement.

\begin{tabular}{|c|c|c|c|}
\hline Authors & Roof Type Studied & Species Studied & Remarks \\
\hline Vandegrift et al. [42] & EGR and IGR & $\begin{array}{l}\text { Herbaceous perennials, sedums, } \\
\text { and grasses }\end{array}$ & $\begin{array}{l}\text { Deep substrates with } \\
\text { maintenance (irrigation). }\end{array}$ \\
\hline Ksiazek-Mikenas et al. [48] & Not specified & Genetically diverse plants & Not specified \\
\hline McKinney et al. [49] & $\begin{array}{l}\text { Low- to high- } \\
\text { maintenance GRs }\end{array}$ & Land snails & $\begin{array}{l}\text { Better maintained and } \\
\text { large-sized roofs. }\end{array}$ \\
\hline Joimel et al. [47] & EGR and IGR & $\begin{array}{l}\text { Arthropods-collembolan } \\
\text { communities }\end{array}$ & $\begin{array}{l}\text { Both types can support soil } \\
\text { biodiversity. }\end{array}$ \\
\hline Partridge and Clark [38] & $\begin{array}{c}\text { IGR, semi-intensive GR, } \\
\text { and EGR }\end{array}$ & $\begin{array}{l}\text { Migrating and breeding birds. } \\
\text { Tree sparrows, spotted doves, } \\
\text { red-whiskered bulbuls, and } \\
\text { Chinese bulbuls were mostly } \\
\text { spotted. }\end{array}$ & $\begin{array}{l}\text { All roof types are suitable. The } \\
\text { presence of birds in their } \\
\text { breeding season depends on } \\
\text { suitable conditions on the roof. }\end{array}$ \\
\hline
\end{tabular}


Table 2. Cont.

\begin{tabular}{|c|c|c|c|}
\hline Authors & Roof Type Studied & Species Studied & Remarks \\
\hline Kratschmer et al. [46] & EGR and IGR & Wild bees & $\begin{array}{l}\text { Both roof types can enhance the } \\
\text { presence of wild bees. IGRs } \\
\text { provide better conditions due to } \\
\text { fine and deep substrate and } \\
\text { variety of floral plants. }\end{array}$ \\
\hline Pétremand et al. [43] & EGR and IGR & Ground beetles & $\begin{array}{l}\text { All types of GRs can support } \\
\text { local species of ground beetles. } \\
\text { However, for conservation, IGRs } \\
\text { might be needed. }\end{array}$ \\
\hline Deng and Jim [39] & EGRs & $\begin{array}{l}\text { Spontaneous plant species and } \\
\text { birds, such as spotted doves, } \\
\text { yellow-crested cockatoos, white } \\
\text { wagtails, red-whiskered bulbuls, } \\
\text { Chinese bulbuls, tree sparrows. }\end{array}$ & $\begin{array}{l}\text { Large EGRs can provide habitats } \\
\text { for birds. }\end{array}$ \\
\hline Wang et al. [40] & Urban roof gardens & $\begin{array}{c}\text { Birds (Javanese myna, } \\
\text { olivebacked sunbird, rock pigeon) } \\
\text { and butterflies (Zizula hylax } \\
\text { pygmaea, Zizina otis lampa). }\end{array}$ & $\begin{array}{l}\text { Roofs with height less than } 50 \mathrm{~m} \text {, } \\
\text { planted areas larger than } \\
1100 \mathrm{~m}^{2} \text {, as well as shrubs. }\end{array}$ \\
\hline Braaker et al. [50] & EGR & Arthropods & $\begin{array}{l}\text { EGRs can support arthropod } \\
\text { diversity across different } \\
\text { taxonomic groups. }\end{array}$ \\
\hline Wong and Jim [36] & EGR & Vector mosquitoes & $\begin{array}{l}\text { Mosquitoes were lesser than in } \\
\text { ground gardens but still } \\
\text { significant in number. }\end{array}$ \\
\hline Washburn et al. [37] & EGR & $\begin{array}{l}\text { Bird species-killdeer, European } \\
\text { starlings, and mourning doves. }\end{array}$ & $\begin{array}{l}\text { GRs support a wide variety of } \\
\text { birds. Birds with a high risk of } \\
\text { strikes with airplanes were } \\
\text { limited on GRs. }\end{array}$ \\
\hline Madre et al. [45] & IGR and EGR & Wild plant species & $\begin{array}{l}\text { Most of the types support the } \\
\text { development of wild species on } \\
\text { GRs. However, the variety of } \\
\text { these species can be enhanced by } \\
\text { increasing the substrate depth. }\end{array}$ \\
\hline Benvenuti [51] & EGR & Wildflowers & $\begin{array}{l}\text { EGRs can support wildflower } \\
\text { development and can be an } \\
\text { alternative to sedum. However, } \\
\text { needs irrigation. }\end{array}$ \\
\hline Madre et al. [44] & $\begin{array}{l}\text { IGR, semi-intensive and } \\
\text { EGR }\end{array}$ & $\begin{array}{l}\text { Arthropods (spiders, true bugs, } \\
\text { beetles, and hymenopterans). }\end{array}$ & $\begin{array}{l}\text { Species richness and abundance } \\
\text { were higher on IGRs. }\end{array}$ \\
\hline Rumble and Gange [52] & EGR & $\begin{array}{l}\text { Microarthropods/soil } \\
\text { biodiversity. }\end{array}$ & $\begin{array}{l}\text { Microarthropods in EGRs were } \\
\text { lesser, limiting the success of } \\
\text { above-ground flora fauna. }\end{array}$ \\
\hline
\end{tabular}

\subsubsection{Water Management}

Stormwater Retention

Table 3 presents the water retention capacities given in the selected literature and the type of roof that was studied along with its respective details. Due to better feasibility, most studies focus on EGRs. We noticed that in some of the cases, GRs could retain the rainfall/runoff completely. In some of the studies, the retention capacity of a GR was reported to be below $10 \%$. The parameters affecting the retention values are rainfall intensity and duration for most of the studies. The retention capacity of a GR is lower in the case of high-intensity rainfall in a short time as compared to medium intensity 
rainfall for a relatively long time. Rainfall characteristics have been discussed to be the most important parameter for deciding the water retention capacity of GRs. Additionally, evapotranspiration and the antecedent dry weather period (ADWP) also influence the retention capacity of GRs.

Table 3. Water retention capacities, as reported in the literature, and their details.

\begin{tabular}{|c|c|c|}
\hline Authors & $\begin{array}{l}\text { Water Retention } \\
\text { Capacity }\end{array}$ & Influencing Factors and Remarks \\
\hline Palermo et al. [53] & $68 \%$ & $\begin{array}{l}\text { EGR, experimental study, substrate depth. } \\
\text { Substrate depth change did not affect } \\
\text { retention capacity. }\end{array}$ \\
\hline $\begin{array}{c}\text { Burszta- } \\
\text { Adamiak et al. [54] }\end{array}$ & $33.6-81 \%$ & $\begin{array}{l}\text { EGR, experimental study, rainfall intensity. } \\
\text { High rainfall intensity led to low retention. }\end{array}$ \\
\hline Talebi et al. [55] & $17-50 \%$ & $\begin{array}{l}\text { EGR, model-based study, vegetation type } \\
\text { (high/low water use), substrate depth, porosity. } \\
\text { High water-use vegetation was more suitable for } \\
\text { retention. Substrate depth and porosity had a } \\
\text { marginal effect on retention. }\end{array}$ \\
\hline X. Liu and Chui [56] & $1-50 \%$ & $\begin{array}{l}\text { EGR, model-based study, rainfall return period. } \\
\text { Amount/percentage of peak and average runoff } \\
\text { reduction increase/decrease with increase in the } \\
\text { duration of the return period }\end{array}$ \\
\hline Sims et al. [57] & $58 \%$ & $\begin{array}{l}\text { EGR, experiment and model-based study, } \\
\text { GR processes. } \\
\text { GR drainage response depended on processes } \\
\text { such as capillary storage, field capacity, and } \\
\text { drainage routing. }\end{array}$ \\
\hline Yin et al. [58] & $11-100 \%$ & $\begin{array}{l}\text { EGR, experimental study, rainfall intensity, } \\
\text { stages of rainfall, substrate moisture content, } \\
\text { solar radiation. Early stages of rainfall can be } \\
\text { retained, low substrate moisture content was } \\
\text { better, increased solar radiation was better }\end{array}$ \\
\hline W. Liu et al. [59] & $6.7-42.1 \%$ & $\begin{array}{l}\text { EGR, experimental study, substrate material } \\
\text { (composition, pore size distribution, and the } \\
\text { maximum water holding capacity) > substrate } \\
\text { depth > slope > vegetation. Deep, porous, with } \\
\text { better water holding capacity substrate and a flat } \\
\text { roof enhanced retention capacity. }\end{array}$ \\
\hline Longobardi et al. [60] & $10-90 \%$ & $\begin{array}{l}\text { EGR, experimental study, initial substrate } \\
\text { moisture, rainfall intensity. } \\
\text { If initial substrate moisture was high and rainfall } \\
\text { was intense, the retention capacity was reduced. }\end{array}$ \\
\hline Schultz et al. [61] & $23.2-32.9 \%$ & $\begin{array}{l}\text { EGR, experimental study, substrate depth, length } \\
\text { of antecedent dry period, evapotranspiration. } \\
\text { Thus, high retention in dry summer months and } \\
\text { lower retention in wetter winter months. }\end{array}$ \\
\hline Harada et al. [62] & $-11 \%$ & $\begin{array}{l}\text { Urban rooftop farm, experimental study, } \\
\text { evapotranspiration and irrigation requirement, } \\
\text { less evapotranspiration, more irrigation } \\
\text { requirement, less soil water storage. }\end{array}$ \\
\hline Abualfaraj et al. [63] & $77 \%$ & $\begin{array}{l}\text { EGR, experimental study, substrate depth, } \\
\text { rainfall volume. Increased precipitation with } \\
\text { warmer temperatures could decrease retention } \\
\text { irrespective of depth. }\end{array}$ \\
\hline
\end{tabular}


Table 3. Cont.

\begin{tabular}{|c|c|c|}
\hline Authors & $\begin{array}{l}\text { Water Retention } \\
\text { Capacity }\end{array}$ & Influencing Factors and Remarks \\
\hline Shafique et al. [64] & $10-60 \%$ & $\begin{array}{l}\text { EGR, experimental study, rainfall intensity } \\
\text { and duration. } \\
\text { Intense rainfalls with longer duration resulted in } \\
\text { a lower percentage of water retention. }\end{array}$ \\
\hline Piro et al. [65] & $57.50 \%$ & $\begin{array}{l}\text { EGR, experimental study, weather conditions } \\
\text { before a rainfall event and the hydrological } \\
\text { features of the stormwater event. } \\
\text { Warmer months before a heavy rainfall gives } \\
\text { better retention as compared to cloudy and rainy } \\
\text { weather due to better evapotranspiration. }\end{array}$ \\
\hline Viola et al. [66] & $47.1-59.6 \%$ & $\begin{array}{c}\text { EGR/IGR, model-based study, climatic } \\
\text { variability (evapotranspiration and precipitation } \\
\text { cycles), soil depth. } \\
\text { Deeper substrates mean better retention. } \\
\text { Evapotranspiration and precipitation cycle in } \\
\text { counter-phase led to less retention. }\end{array}$ \\
\hline Cipolla et al. [67] & $6.4-100 \%$ & $\begin{array}{l}\text { EGR, experimental study, rainfall depth, } \\
\text { intensity, and return period. } \\
\text { Moderate rainfall depth, intensity, and return } \\
\text { period, better retention. }\end{array}$ \\
\hline Elliott et al. [68] & $10-100 \%$ & $\begin{array}{l}\text { EGR, experimental study, antecedent dry } \\
\text { weather periods (ADWP), weather, } \\
\text { evapotranspiration, and substrate depth. } \\
\text { Longer ADWP, warmer months, better } \\
\text { evapotranspiration, deeper substrate } \\
\text { performed better. }\end{array}$ \\
\hline Kok et al. [69] & $26 \% \max$ & $\begin{array}{l}\text { EGR, experimental study, rainfall intensity. } \\
\text { Intense rainfall resulted in lower retention. }\end{array}$ \\
\hline Sims et al. [70] & $34-67 \%$ & $\begin{array}{l}\text { EGR, experiment-model based, field capacity } \\
\text { of GRs. } \\
\text { Better field capacity is important for } \\
\text { effective retention. }\end{array}$ \\
\hline $\begin{array}{l}\text { Sobczyk and } \\
\text { Mrowiec [71] }\end{array}$ & $30-50 \%$ & $\begin{array}{l}\text { EGR, experimental study, substrate depth, } \\
\text { ADWP, and rainfall return period. } \\
\text { Longer ADWP and rainfall return period, } \\
\text { better retention. }\end{array}$ \\
\hline J. Y. Lee et al. [72] & $13.8-60 \%$ & $\begin{array}{l}\text { EGR, experimental study, ADWP, rainfall } \\
\text { intensity, soil depth. } \\
\text { Longer ADWP with high rainfall intensity and } \\
\text { deeper substrate resulted in better retention. }\end{array}$ \\
\hline Nawaz et al. [73] & $3.6-100 \%$ & $\begin{array}{c}\text { EGR, experimental study, rainfall depth, } \\
\text { duration, intensity, ADWP. } \\
\text { ADWP not a significant factor in a temperate } \\
\text { climate as evapotranspiration is mostly low; } \\
\text { shorter rainfalls are retained better than } \\
\text { larger rainfalls. }\end{array}$ \\
\hline Wong and Jim [74] & $15.7-83.9 \%$ & $\begin{array}{l}\text { EGR, experimental study, rainfall intensity, } \\
\text { duration, substrate depth. } \\
\text { Retention less effective with heavy rainfall } \\
\text { regime in the region; however, peak retention } \\
\text { and delay was still significant. }\end{array}$ \\
\hline
\end{tabular}


Table 3. Cont.

\begin{tabular}{|c|c|c|}
\hline Authors & $\begin{array}{l}\text { Water Retention } \\
\text { Capacity }\end{array}$ & Influencing Factors and Remarks \\
\hline Hakimdavar et al. [75] & $32-85 \%$ & $\begin{array}{l}\text { EGR, experimental study, rainfall depth and } \\
\text { duration, ADWP. } \\
\text { Rainfall depth and duration influenced more } \\
\text { than the ADWP and rainfall intensity. }\end{array}$ \\
\hline $\begin{array}{l}\text { Oviedo Escobar and } \\
\text { Torres [76] }\end{array}$ & $80 \% \max$ & $\begin{array}{l}\text { EGR, experimental study, vegetation type. } \\
\text { Species other than sedum, an herbaceous plant } \\
\text { (Lactuca sativa) and a Cruciferae (Raphanus } \\
\text { sativus), found effective in water retention. }\end{array}$ \\
\hline Locatelli et al. [77] & $2-78 \%$ & $\begin{array}{l}\text { EGR, model-based study, rainfall return period. } \\
\text { Extended rainfall return periods retained better. }\end{array}$ \\
\hline J. Y. Lee et al. [78] & $50 \%-100 \%$ & $\begin{array}{l}\text { EGR, experimental study, rainfall intensity. } \\
\text { Intense rainfalls were challenging to retain. }\end{array}$ \\
\hline Ekşi [79] & $12.8-100 \%$ & $\begin{array}{c}\text { EGR, experimental study, duration and } \\
\text { rainfall intensity. } \\
\text { Longer duration of intense rainfall was difficult } \\
\text { to retain. }\end{array}$ \\
\hline Rosatto et al. [80] & $30-100 \%$ & $\begin{array}{l}\text { EGR, experimental study, rainfall intensity, } \\
\text { substrate depth. } \\
\text { Rainfall intensity influenced retention. Slight } \\
\text { differences observed in substrate depths, deeper } \\
\text { substrates were better. }\end{array}$ \\
\hline Speak et al. [81] & $65.7 \%$ avg & $\begin{array}{c}\text { IGR, experimental study, age of GR, } \\
\text { rainfall amount. } \\
\text { Aged GRs retained rainfall better than the } \\
\text { new GRs. }\end{array}$ \\
\hline Carson et al. [82] & $36-71 \%$ & $\begin{array}{l}\text { EGR, experimental study, rainfall event size. } \\
\text { Low to moderate rainfalls were retained better } \\
\text { than intense ones. Retention was better in } \\
\text { summer than winter. }\end{array}$ \\
\hline Burszta-Adamiak [83] & $25-100 \%$ & $\begin{array}{l}\text { EGR, experimental study, rainfall volume. } \\
\text { Retention was better than bare roofs for } \\
\text { all events. }\end{array}$ \\
\hline Buccola and Spolek [84] & $20-36 \%$ & $\begin{array}{l}\text { EGR, experimental study, substrate depth. } \\
\text { Deeper substrates retained rainfall better. }\end{array}$ \\
\hline
\end{tabular}

Substrate depth is also one of the important parameters [63,71]. Generally, deeper substrate corresponds with better retention capacity. However, a deep substrate might not be feasible for implementation. The evidence suggests that EGRs with shallow substrates are perfectly capable of managing stormwater. For instance, Wong and Jim [74] observed that both IGRs and EGRs have a significant performance. Some studies discuss various materials to be used in the substrate for the better retention of GRs as well $[55,59,81]$. The use of organic matter or recycled materials can be helpful [81]; however, this parameter has been of lower importance as compared to other parameters [59]. Vegetation type also influences the water retention capacity of GRs. Taller plants with deep roots can be useful for retaining water as compared to sedum species [81]. In addition to the aforementioned design parameters, field capacity, the capillary storage of substrate, and drainage routing also play an important role in water retention by GRs [57]. 


\section{Flood Mitigation}

This section discusses the six selected studies that were carried out at a larger scale (at a neighborhood or city level) to understand the capacity of GRs to reduce the impact of floods.

Versini et al. [85] reported that when more than $50 \%$ of potential roofs are green (EGRs), the reduction in hydrological response in terms of peak and volume of runoff can reach around $20 \%$ in the case of rainfall with a return period lower than ten years. However, the impact of EGRs for intense rainfalls is marginal. The performance of a GR depends upon the precipitation and initial substrate saturation. Higher precipitation results in higher substrate saturation. If the GR is experiencing frequent rainfalls, the discharge is higher with subsequent rainfalls depending on the substrate saturation level. Thus, Versini et al. [86] argue that GR performance is more effective in the case of short-duration (but sometimes intense) rainfall. Additionally, they observe that the total area of GRs is more important than their location in terms of reducing the total runoff volume. However, the spatial distribution of GRs also affects the reduction in peak discharge; for instance, greening the roofs in the upstream region is observed to be more beneficial in delaying the catchment runoff rather than downstream where cascading effects can occur [86]. Schmitter et al. [87] observed that the annual volume reductions were low but substantial in terms of flood protection when all traditional roofs were converted to GRs.

Mora-Melià et al. [88] reported that floods could be avoided if at least $50 \%$ of the building roofs in the study area were covered with GRs in the case of moderate rainfall. For extreme storm events, semi-intensive GRs covering $60-100 \%$ of the study area could prevent floods. The efficiency of GR implementation is suggested to be further dependent upon the vegetation type and substrate depth. However, even if IGRs are implemented at a city scale, Ercolani et al. [89] have observed that efficiency is better for smaller storm events. They also point out that the efficiency is dependent upon the sewer characteristics and structural improvements in terms of sewer relining or the enlargement of conduits. Additionally, EGR performance is observed to be marginally useful in the case of flash floods [90].

\section{Runoff Water Quality}

Urban stormwater runoff carries urban non-point source pollution, affecting water quality [91]. GRs have the potential to reduce runoff quantity, while their impact on runoff quality is debatable. We identified around 19 studies related to this. We mainly observed studies examining the concentrations of nutrients, namely total nitrogen (TN), total phosphorus (TP), total suspended solids (TSS), chemical oxygen demand (COD), ammonium compounds $\left(\mathrm{NH}_{4}{ }^{+}-\mathrm{N}\right)$, phosphates $\left(\mathrm{PO}_{4}{ }^{3-}\right)$, and nitrates $\left(\mathrm{NO}_{3}{ }^{-}\right)$(Table 4$)$. Moreover, the literature also shows evidence related to hard metals such as zinc ( $\mathrm{Zn}$ ), iron $(\mathrm{Fe})$, copper $(\mathrm{Cu})$, and lead $(\mathrm{Pb})$ (Table 5). In Tables 4 and 5, we report whether the GRs are the source or sink of the nutrients and metals, respectively. GRs are a source of pollutants if the pollutants are greater in the runoff than in the rainwater or in the runoff from bare roofs; otherwise, they are sinks [92].

When GR runoff leachate is compared to the initial rainwater quality, the concentration of TP, TN, K, nitrates, and phosphates are higher in GR runoff, meaning GRs are a source of these nutrients $[93,94]$. Nevertheless, when compared to bare roofs, GRs, especially EGRs, often act as sinks for nitrogen, nitrates, and TSS $[95,96]$. However, the concentrations of phosphorus and phosphates are usually similar to the runoff observed from bare roofs or are higher in GR runoff due to the presence of fertilizers in the substrates [97]. Thus, the review suggests that GRs are a significant source of phosphates. Although GRs are a source of phosphates in the runoff, some studies have reported the concentrations to be well within the standards for non-potable water use in some regions $[98,99]$. Therefore, there is a potential to reuse the runoff from EGRs for non-potable purposes and avoid the direct flow of runoff into water bodies. Roof gardens or IGRs, due to excess fertilizers and 
thicker substrates, release a significant amount of total phosphorus and potassium and so the runoff cannot be reused [10,99-101].

Another finding is that the concentration of TSS, COD, and ammonium in the runoff decrease over the years, whereas the concentration of nitrates increases over time, and that of TP remains the same $[93,102]$. Usually, the first flush after an intermittent dry period results in many nutrients in the runoff. The concentrations reduce in consequent rainfalls [103]. Mostly, the studies suggest that GRs appear to be a source of nutrients such as nitrates and phosphates. However, amending the GRs with appropriate substrate materials, thickness, and vegetation types could improve the runoff water quality.

Table 4. Sources and sinks of nutrients in GR runoff, according to the review.

\begin{tabular}{|c|c|c|c|c|c|c|c|c|c|c|}
\hline \multirow{2}{*}{ Authors } & \multirow{2}{*}{ Influencing Factors } & \multicolumn{9}{|c|}{ Nutrients } \\
\hline & & TP & TN & K & $\mathrm{NO}_{3}{ }^{-}$ & $\mathrm{PO}_{4}{ }^{3-}$ & $\mathrm{Cl}^{-}$ & $\mathrm{NH}_{4}{ }^{+}-\mathrm{N}$ & TSS & COD \\
\hline $\begin{array}{l}\text { Gregoire and } \\
\text { Clausen [104] }\end{array}$ & Substrate material & $\bullet$ & $x$ & & $\mathrm{x}$ & $\bullet$ & & & & \\
\hline Vijayaraghavan et al. [98] & $\begin{array}{l}\text { Substrate materials, } \\
\text { rainfall volume }\end{array}$ & & & o & o & $\Delta$ & & & & \\
\hline Gnecco et al. [105] & $\begin{array}{l}\text { Substrate material, } \\
\text { maintenance } \\
\text { activities }\end{array}$ & & & $\bullet$ & & & & & $\bullet$ & $\bullet$ \\
\hline Speak et al. [95] & GR age & & & & $\mathrm{x}$ & $\bullet$ & & & & \\
\hline Razzaghmanesh et al. [101] & Type of GR & o & & o & o & & & & o & \\
\hline Whittinghill et al. [100] & $\begin{array}{l}\text { Type of GR } \\
\text { (roof garden) }\end{array}$ & $\Delta$ & o & $\Delta$ & & & & & o & \\
\hline $\begin{array}{c}\text { Beecham and } \\
\text { Razzaghmanesh [103] }\end{array}$ & $\begin{array}{l}\text { Organic substrate, } \\
\text { vegetation, type of } \\
\text { roof (IGR/EGR) }\end{array}$ & & & & $\bullet$ & $\bullet$ & & & & \\
\hline Whittinghill et al. [99] & Vegetation type & o & & & o & & & & & \\
\hline Chen and Kang [102] & $\begin{array}{l}\text { Substrate material, } \\
\text { vegetation type }\end{array}$ & $\bullet$ & $\bullet$ & & & & & & $\bullet$ & $\bullet$ \\
\hline $\begin{array}{c}\text { Kuoppamäki and } \\
\text { Lehvävirta [106] }\end{array}$ & $\begin{array}{l}\text { Substrate material, } \\
\text { vegetation type }\end{array}$ & $\bullet$ & $\bullet$ & & & & & & & \\
\hline Kuoppamäki et al. [94] & Substrate material & $\bullet$ & $\bullet$ & & & & & & & \\
\hline Todorov et al. [97] & $\begin{array}{l}\text { Rainfall intensity, } \\
\text { vegetated EGR }\end{array}$ & $\bullet$ & $\mathrm{x}$ & & $\mathrm{x}$ & $\bullet$ & $\mathrm{x}$ & $\mathrm{x}$ & & \\
\hline Chai et al. [93] & $\begin{array}{l}\text { Vegetation type, } \\
\text { substrate material, } \\
\text { substrate thickness, } \\
\text { rainfall quality }\end{array}$ & $\bullet$ & $\bullet$ & & $\bullet$ & & & $\bullet$ & $\bullet$ & $\bullet$ \\
\hline Okita et al. [107] & GR age & $\bullet$ & & & & $\bullet$ & & & & \\
\hline Karczmarczyk et al. [108] & Substrate material & $\bullet$ & & & & $\bullet$ & & & & \\
\hline W. Liu, et al. [10] & $\begin{array}{c}\text { Substrate } \\
\text { material/thickness, } \\
\text { vegetation type }\end{array}$ & $\bullet$ & $\bullet$ & & & & & & $\bullet$ & \\
\hline Qianqian et al. [91] & Substrate material & $\bullet$ & o & & & & & & $\bullet$ & o \\
\hline Gong et al. [96] & Substrate thickness & $\mathrm{x}$ & $\mathrm{x}$ & & $x$ & & & $\mathrm{x}$ & & $\bullet$ \\
\hline
\end{tabular}

Apart from nutrients, runoff from GRs also contains metal pollutants. Table 5 suggests that, in the reported studies, GRs behave as a sink for most metals. However, aged GRs (43 years old), although aiding in reducing the concentrations of nutrients, release additional amounts of metals such as $\mathrm{Cu}, \mathrm{Zn}, \mathrm{Fe}$, and $\mathrm{Pb}$ in the runoff as compared to bare roofs [94]. Supporting this argument, Okita et al. [107] also reported that a sixyear-old GR has similar concentrations of $\mathrm{Cu}$ as compared to bare roofs. Apart from this, Alsup et al. [109] have observed that a GR's behavior as a sink or source of metals fluctuates depending upon the substrate properties and the dry and wet deposition of metals. Substrate materials such as expanded clay and organic materials have been effective in reducing $\mathrm{Zn}$ and $\mathrm{Cu}$ concentrations [110]. 
Table 5. Sources and sinks of metal pollutants from GR runoff.

\begin{tabular}{|c|c|c|c|c|c|c|c|c|c|c|c|c|c|}
\hline \multirow{2}{*}{ Authors } & \multirow{2}{*}{ Influencing Factors } & \multicolumn{9}{|c|}{ Metals } & \multirow[b]{2}{*}{ Mn } & \multirow[b]{2}{*}{$\mathrm{Cr}$} & \multirow[b]{2}{*}{$\mathrm{Ni}$} \\
\hline & & $\mathrm{Cu}$ & $\mathrm{Zn}$ & $\mathrm{Fe}$ & $\mathrm{Na}$ & $\mathrm{Ca}$ & $\mathrm{Mg}$ & Al & $\mathrm{Cd}$ & $\mathbf{P b}$ & & & \\
\hline Gregoire and Clausen [104] & Substrate material & • & $\mathrm{x}$ & & & & & & $\mathrm{x}$ & & & & \\
\hline Vijayaraghavan et al. [98] & $\begin{array}{l}\text { Substrate material, } \\
\text { rainfall volume }\end{array}$ & $\Delta$ & & o & o & o & o & $\Delta$ & & & & & \\
\hline Gnecco et al. [105] & $\begin{array}{l}\text { Substrate material, } \\
\text { maintenance } \\
\text { activities }\end{array}$ & $\mathrm{x}$ & $\mathrm{x}$ & & & & & & & & & & \\
\hline Alsup et al. [109] & $\begin{array}{l}\text { Substrate material, } \\
\text { vegetation type }\end{array}$ & $\bullet / \mathrm{x}$ & $\bullet / x$ & & & & & & $\bullet / x$ & $\bullet / x$ & & & \\
\hline Speak et al. [95] & Aged GR & $\Delta$ & $\Delta$ & & & & & & & $\Delta$ & & & \\
\hline Razzaghmanesh et al. [101] & $\begin{array}{l}\text { Soil thickness in the } \\
\text { substrate }\end{array}$ & o & o & o & & & & & & $\mathrm{o}$ & o & & \\
\hline Schwager et al. [110] & Substrate material & $x$ & $x$ & & & & & & & & & & \\
\hline Whittinghill et al. [100] & Type of GR & & & & & $\bullet$ & $\bullet$ & & & & & & \\
\hline $\begin{array}{l}\text { Kuoppamäki and } \\
\text { Lehvävirta [106] }\end{array}$ & Substrate material & $\mathrm{x}$ & $\mathrm{x}$ & & & & & & & & $\bullet$ & $\mathrm{x}$ & $\mathrm{x}$ \\
\hline Okita et al. [107] & GR age & $\bullet$ & $x$ & & & & & & & & & & \\
\hline Qianqian et al. [91] & Substrate material & & & $\mathrm{o}$ & & & & & & & & & \\
\hline
\end{tabular}

\subsubsection{UHI}

In this section, we report the results of 39 studies and discuss the impact of GRs on the UHI effect regarding the following four aspects: roof surface temperature, energy savings, air (outdoor, area above the roof) temperature, and human thermal comfort (indoor and street-level temperatures).

\section{Roof Surface Temperature}

The reduction in surface temperature due to the implementation of GRs ranges from 1 to $46^{\circ} \mathrm{C}$ depending upon various factors, such as the type of GR, weather conditions, climate zones, substrate properties, and type of vegetation (Table 6). The surface temperature after roof greening does not reduce significantly in winters and cold climatic conditions. Another important finding is that GRs have different impacts on roof surface temperature depending upon the time of the day. The direction of heat flux is top to bottom during the day and reverses during the night [111]. As a result, the GR surface cools during the day and warms at night $[112,113]$. This effect is more prominent in IGRs than EGRs as deeper systems gain more heat [112].

Table 6. Surface temperature reduction, as reported in selected studies after implementing GRs, and respective details.

\begin{tabular}{ccc}
\hline Authors & $\begin{array}{c}\text { Surface Temperature } \\
\text { Reduction }\end{array}$ & Details \\
\hline Peng et al. [112] & $\begin{array}{c}\text { Summer-14.8 to } 15.8^{\circ} \mathrm{C} \\
\text { Winter-7.3 to } 9.4{ }^{\circ} \mathrm{C}\end{array}$ & $\begin{array}{c}\text { China, large-scale EGR and IGR, experimental } \\
\text { study, humid subtropical climate. }\end{array}$ \\
\hline Fitchett et al. [118] & $5-10^{\circ} \mathrm{C}$ & $\begin{array}{c}\text { South African region, EGR, experimental } \\
\text { study, dry winter season. }\end{array}$ \\
\hline Hirano et al. [119] & $10{ }^{\circ} \mathrm{C}$ & $\begin{array}{c}\text { Tokyo, Japan, EGR, model-based study, } \\
\text { summer, 21 m building height, greening area } \\
\text { (0, 50\%, 100\%). }\end{array}$ \\
\hline L. S. H. Lee and Jim [120] & $4.9{ }^{\circ} \mathrm{C}$ & $\begin{array}{c}\text { Hong Kong, IGR, experimental study, } \\
\text { summer-daytime. }\end{array}$ \\
\hline Bevilacqua et al. [121] & $42-46{ }^{\circ} \mathrm{C}$ & $\begin{array}{c}\text { Southern Italy, EGR, experimental study, } \\
\text { summer, } \\
\text { high water content led to greater } \\
\text { temperature reduction. }\end{array}$ \\
\hline
\end{tabular}


Table 6. Cont.

\begin{tabular}{|c|c|c|}
\hline Authors & $\begin{array}{l}\text { Surface Temperature } \\
\text { Reduction }\end{array}$ & Details \\
\hline Alvizuri et al. [122] & $16^{\circ} \mathrm{C}$ & $\begin{array}{c}\text { New York, EGR, experimental study, summer, } \\
\text { yearly experiment, } \\
\text { no significant difference in winter. }\end{array}$ \\
\hline Foustalieraki et al. [123] & $21.9^{\circ} \mathrm{C}$ & $\begin{array}{l}\text { Athens, Greece, EGR, experimental study, cold } \\
\text { period, dense foliage plants resulted in } \\
\text { lower temperatures. }\end{array}$ \\
\hline Razzaghmanesh et al. [111] & $2-5^{\circ} \mathrm{C}$ & $\begin{array}{c}\text { Adelaide, Australia, IGR and EGR, } \\
\text { experimental study, hot Mediterranean } \\
\text { climate, summer - daytime, substrate material. }\end{array}$ \\
\hline Gagliano et al. [124] & $27.7^{\circ} \mathrm{C}$ & $\begin{array}{l}\text { Southern Italy, EGR, experimental study, } \\
\text { Mediterranean climate, summer. High LAI, } \\
\text { greater temperature reduction. }\end{array}$ \\
\hline Gagliano et al. [114] & $18^{\circ} \mathrm{C}$ & $\begin{array}{l}\text { Southern Italy, EGR, model-based study, } \\
\text { thermal insulation. } \\
\text { Thicker insulation, more reduction } \\
\text { in temperature. }\end{array}$ \\
\hline Karachaliou et al. [115] & $15^{\circ} \mathrm{C}$ & $\begin{array}{l}\text { Athens, Greece, IGR, experimental study, } \\
\text { summer period, Mediterranean climate, type } \\
\text { of plants. } \\
\text { Plants with low absorptivity to solar radiation, } \\
\text { dense foliage, resulted in lower temperatures. }\end{array}$ \\
\hline He et al. [116] & $5^{\circ} \mathrm{C}$ & $\begin{array}{l}\text { Shanghai, China, EGR, experimental study, } \\
\text { north subtropical monsoon climate, summer, } \\
\text { soil water content, solar radiation, and } \\
\text { outdoor temperature (longwave radiation). } \\
\text { Cooling effect more pronounced on sunny } \\
\text { days. Solar radiation correlated the most with } \\
\text { heat flux. }\end{array}$ \\
\hline $\begin{array}{l}\text { Wilkinson and } \\
\text { Feitosa [125] }\end{array}$ & $\begin{array}{c}\text { Sydney-5.6 } \\
\text { Rio de Janeiro- } 14.8^{\circ} \mathrm{C}\end{array}$ & $\begin{array}{l}\text { Sydney and Rio de Janeiro, lightweight and } \\
\text { portable EGR, experimental study. } \\
\text { Reduction depended upon the shadow and } \\
\text { sun radiation received. }\end{array}$ \\
\hline Lin et al. [113] & $\begin{array}{l}\text { Night-time: } \\
3.4^{\circ} \mathrm{C} \text { to } 4.6^{\circ} \mathrm{C} \text {-Taipei } \\
3.1^{\circ} \mathrm{C} \text { to } 3.8^{\circ} \mathrm{C} \text {-Chiayi. } \\
\text { Afternoon: } \\
1.0^{\circ} \mathrm{C} \text { to } 13.6^{\circ} \mathrm{C} \text {-Taipei } \\
6.5^{\circ} \mathrm{C} \text { to } 17.1^{\circ} \mathrm{C} \text {-Chiayi }\end{array}$ & $\begin{array}{l}\text { Taipei and Chiayi, Taiwan, EGR, experimental } \\
\text { study, rainfall, different times of the day and } \\
\text { different climatic conditions. }\end{array}$ \\
\hline Theodosiou et al. [126] & $\begin{array}{l}\text { Summer- } 11.5^{\circ} \mathrm{C} \\
\text { Winter- }-3.7^{\circ} \mathrm{C}\end{array}$ & $\begin{array}{c}\text { Thessaloniki, Greece, EGR, experimental study, } \\
\text { Mediterranean climate. Seasonal differences } \\
\text { affected reduction. }\end{array}$ \\
\hline Dvorak and Volder [117] & $18^{\circ} \mathrm{C}$ & $\begin{array}{l}\text { South Texas, EGR, experimental study, dry } \\
\text { summer conditions, } \\
\text { soil volumetric water content-did not affect } \\
\text { much; thus, unirrigated succulents can be } \\
\text { used for reducing the temperature. }\end{array}$ \\
\hline Liang and Huang [127] & 3.6 to $30.1^{\circ} \mathrm{C}$ & $\begin{array}{l}\text { Taiwan, IGR planted with a lawn, } \\
\text { experimental study, Summer }\end{array}$ \\
\hline
\end{tabular}

Vegetation properties such as high foliage density and high leaf area index (LAI) aid in improving the performance of GRs $[114,115]$. Additionally, lower albedo and evapotranspiration due to large soil water content in GRs also aid in lowering surface temperatures [116]. However, Dvorak and Volder [117] reported that GRs with low soil water content are also equally effective in reducing the surface temperature in extreme dry summers.

\section{Energy Savings}

Table 7 presents the findings from the selected literature and indicates that GRs help with saving considerable energy, especially in summer. In summer, a reduction in the heat 
gain from the roof slab leads to a decrease in the cooling loads. However, in winter, heating loads have been reported to increase due to a reduction in heat gain during the day and an increase in heat loss during the night [112].

Berardi [128] reported that using appropriate substrate materials (greater depth) and vegetation types (high LAI) with lower U-values (thermal transmittance) can aid in reducing the heating load in winter. Karachaliou et al. [115] have observed that IGRs are effective in reducing heating loads, but not as effective at reducing cooling loads in summer. The effect of the reduction in cooling and heating loads is more prominent on the topmost floors, and the rooms on other floors only experience marginal changes [115]. Apart from this, additional insulation has also been observed to aid in reducing heating loads; however, the efficiency is dependent upon climatic conditions. For instance, Kotsiris et al. [129] observed that insulation is ineffective in the case of the Greek Mediterranean climate, whereas Gagliano et al. [114] and Đorđević et al. [130] observed that insulation works best for heating loads in a moderate continental climate.

Table 7. Energy savings due to GR implementation, as per the selected literature.

\begin{tabular}{|c|c|c|}
\hline Authors & Energy Savings & Details \\
\hline Kotsiris et al. [129] & $\begin{array}{l}-0.3 \% \text { to } 11.6 \% \text {-winter. } \\
2 \% \text { to } 38.12 \% \text {-summer. }\end{array}$ & $\begin{array}{l}\text { Athens, Greece, EGR and } \\
\text { semi-IGR, building scale study. }\end{array}$ \\
\hline Peng et al. [112] & $\begin{array}{l}\text { Summer cooling load decreased } \\
\text { by } 79-86 \% \text {. } \\
\text { Winter heating load increase by } \\
58 \%-92 \% \text {. }\end{array}$ & $\begin{array}{l}\text { China, large-scale EGR and IGR, } \\
\text { humid subtropical climate. }\end{array}$ \\
\hline Dordević et al. [130] & $\begin{array}{l}80 \% \text { reduction in heating load } \\
\text { in winter. }\end{array}$ & $\begin{array}{c}\text { Serbia, EGR, cold climate, } \\
\text { additional thermal insulation and } \\
\text { substrate thickness. }\end{array}$ \\
\hline Foustalieraki et al. [123] & $\begin{array}{l}\text { Reduction in the annual cooling } \\
\text { load up to } 18.7 \% \text { and in the } \\
\text { heating load up to } 11.4 \% \text { in total. }\end{array}$ & $\begin{array}{c}\text { Athens, Greece, EGR, cold period, } \\
\text { dense foliage plants resulted in } \\
\text { lower temperatures. }\end{array}$ \\
\hline Karachaliou et al. [115] & $\begin{array}{l}19.1 \% \text { reduction in cooling load. } \\
11.4 \% \text { reduction in heating load. }\end{array}$ & $\begin{array}{l}\text { Athens, Greece, IGR, summer } \\
\text { period, Mediterranean climate. } \\
\text { Plants with low absorptivity to } \\
\text { solar radiation, dense foliage } \\
\text { resulted in lower temperatures. }\end{array}$ \\
\hline Gagliano et al. [116] & $\begin{array}{l}85 \% \text { reduction in cooling energy } \\
\text { demand, } 15-48 \% \text { reduction in } \\
\text { heating energy demand. } \\
\text { Electricity consumption was } \\
85-92 \% \text { reduced depending } \\
\text { upon insulation }\end{array}$ & $\begin{array}{l}\text { Southern Italy, EGR, thermal } \\
\text { insulation. } \\
\text { Thicker insulation, greater } \\
\text { reduction in temperature. }\end{array}$ \\
\hline Berardi [128] & $\begin{array}{c}\text { Building energy demand } \\
\text { reduced by } 3 \% \text {. } \\
\text { Heating saving by } 9 \% \text {, cooling } \\
\text { saving by } 4 \%\end{array}$ & $\begin{array}{l}\text { Toronto, Canada, EGR, } \\
\text { semi-continental climate. } \\
\text { Increasing the soil depth is more } \\
\text { important than increasing the LAI. } \\
\text { Energy savings were related to } \\
\text { the LAI in summer and to the soil } \\
\text { depth in winter. }\end{array}$ \\
\hline Pandey et al. [131] & $73.8 \%$ savings of peak load. & $\begin{array}{l}\text { Ujjain, India, rooftop garden, } \\
\text { temperate climate, summer day. } \\
\text { Thicker soil, tall foliage reduced } \\
\text { the heat flux. }\end{array}$ \\
\hline
\end{tabular}




\section{Outside Air Temperature}

Table 8 shows the reductions in air temperature near the roofs after the installation of GRs, as reported in the selected literature. Experimental studies have measured the impact of GRs on air temperature at a height ranging from $10 \mathrm{~cm}$ to $300 \mathrm{~cm}$ above the roof. The temperature reduction ranges from 0.5 to $6.1^{\circ} \mathrm{C}$. However, it is essential to know that, except for J. Park et al. [132], other studies reported a reduction of only up to $2{ }^{\circ} \mathrm{C}$. Amongst the studies that used a model-based approach, Heidarinejad and Esmaili [133] reported the highest reduction in air temperature $\left(13^{\circ} \mathrm{C}\right)$. The reason could be the consideration of plant metabolism, including photosynthesis in the model. Validation showed that the model results were similar to a real situation.

It should be noted that the temperature reduction is higher at night as compared to daytime due to the accumulation of thermal energy - which is highest in bare roofs relative to GRs - rather than the latent cooling of GRs [134]. The cooling observed over the GR usually corresponds to the cooling on the surface. If the surface temperature of well-watered and dry GRs was almost the same [134,135], the air temperature above them varied. The main difference the review suggests between these studies is the difference in plant species and substrate depth that reduce the overlaying air temperature, possibly due to higher evapotranspiration. Sedum-type vegetation and thinner substrates might not be an appropriate choice if the aim is to reduce the daytime temperature [135].

Altogether, the evidence suggests that GR installation results in the cooling of the air temperature near the roofs. However, in extreme summers, suitable plants and substrates with appropriate water content might be needed to enhance GR performance.

Table 8. Reduction in air temperature (near the rooftop) after implementing GRs, as reported in the selected studies.

\begin{tabular}{|c|c|c|}
\hline Authors & Air Temperature Reduction & Details \\
\hline Peng et al. [112] & $\begin{array}{l}1.5 \text { to } 2.5(\mathrm{~T} 10 \mathrm{~cm}){ }^{\circ} \mathrm{C} \\
0.5 \text { to } 0.6(\mathrm{~T} 150 \mathrm{~cm}){ }^{\circ} \mathrm{C}\end{array}$ & $\begin{array}{l}\text { China, large-scale EGR and IGR, } \\
\text { experimental study, humid } \\
\text { subtropical climate. } \\
\text { Better reduction by the IGR. }\end{array}$ \\
\hline Hirano et al. [119] & $0.13^{\circ} \mathrm{C}$ (near rooftop) & $\begin{array}{c}\text { Tokyo, Japan, EGR, model-based study, } \\
\text { summer, } 21 \mathrm{~m} \text { building height, greening } \\
\text { area }(0,50 \%, 100 \%) .\end{array}$ \\
\hline L.S.H. Lee and Jim [120] & $1.6^{\circ} \mathrm{C}(1.5 \mathrm{~m})$ & $\begin{array}{l}\text { Hong Kong, IGR, experimental study, } \\
\text { summer-daytime. }\end{array}$ \\
\hline Köhler and Kaiser [136] & $\begin{array}{l}1 \mathrm{~m} \text { above the roof: } 1.5 \mathrm{~K} \text { over } \\
20 \text { years }\end{array}$ & $\begin{array}{l}\text { Neubrandenburg, Germany, EGR, } \\
\text { experimental study, data recorded over } \\
20 \text { years (1999-2018). }\end{array}$ \\
\hline Lalošević et al. [137] & $\begin{array}{c}\mathrm{Up} \text { to EGR-0.53 }{ }^{\circ} \mathrm{C}, \mathrm{IGR}-1.45{ }^{\circ} \mathrm{C} \\
\text { at roof level }\end{array}$ & $\begin{array}{l}\text { Belgrade, Serbia, IGR and EGR, } \\
\text { model-based study, a small } \\
\text { neighborhood was studied. }\end{array}$ \\
\hline J. Park et al. [132] & $\begin{array}{c}\text { During the day and night } \\
\text { Average- } 6.1^{\circ} \mathrm{C} \text { at } 1.5 \mathrm{~m} \text { above the } \\
\text { roof } \\
\text { Day- } 10.8^{\circ} \mathrm{C} \\
\text { Night }-1.0^{\circ} \mathrm{C}\end{array}$ & $\begin{array}{c}\text { Seoul, South Korea, EGR, experimental } \\
\text { study, summer. }\end{array}$ \\
\hline Solcerova et al. [135] & $\begin{array}{c}-0.2^{\circ} \mathrm{C} \\
15 \mathrm{~cm} \text { above roof }\end{array}$ & $\begin{array}{l}\text { Utrecht, Netherlands, EGR, } \\
\text { experimental study, summer period, } \\
\text { sedum-type plants. }\end{array}$ \\
\hline Sisco et al. [138] & 0.7 to $2{ }^{\circ} \mathrm{C}$ near roof & $\begin{array}{l}\text { Beirut, Lebanon, roof garden, } \\
\text { experimental study, recyclable materials. } \\
\text { A/C condensate can be used for } \\
\text { irrigation purposes. }\end{array}$ \\
\hline Mirnezhad et al. [139] & $1-2{ }^{\circ} \mathrm{C}(12-24 \mathrm{~cm}$ above roof $)$ & $\begin{array}{c}\text { Putrajaya, Malaysia, EGR, experimental } \\
\text { study, hot and humid climate, summer. } \\
\text { Thicker substrates result in } \\
\text { better cooling. }\end{array}$ \\
\hline
\end{tabular}


Table 8. Cont.

\begin{tabular}{|c|c|c|}
\hline Authors & Air Temperature Reduction & Details \\
\hline Ebrahimnejad et al. [140] & $\begin{array}{c}0.8^{\circ} \mathrm{C} \\
\text { Above GR }\end{array}$ & $\begin{array}{l}\text { Tehran, Iran, IGR, model-based } \\
\text { study, summer, } \\
\text { GR effect simulated on a bridge and } \\
\text { surrounding area. }\end{array}$ \\
\hline Sun et al. [141] & $\mathrm{T} 150 \mathrm{~cm}=2.5^{\circ} \mathrm{C}$ & $\begin{array}{l}\text { Beijing, China, EGR, model-based } \\
\text { study, summer. } \\
\text { Mesoscale simulation-recording } \\
\text { impact of heatwave. }\end{array}$ \\
\hline $\begin{array}{l}\text { Heidarinejad and } \\
\text { Esmaili [133] }\end{array}$ & $13{ }^{\circ} \mathrm{C}(1 \mathrm{~m}$ above $)$ & $\begin{array}{c}\text { Tehran, Iran, EGR, model-based study, } \\
\text { plant metabolism. Influence of plants on } \\
\text { heat reduction. }\end{array}$ \\
\hline Klein and Coffman [142] & $1^{\circ} \mathrm{C} \max (1.5 \mathrm{~m})$ & $\begin{array}{c}\text { Norman, Oklahoma, EGR, experimental } \\
\text { study, plant species, humidity increase } \\
\text { of only } 2 \% \text {. }\end{array}$ \\
\hline Speak et al. [134] & $\begin{array}{c}1.06^{\circ} \mathrm{C} \text { (day) } \\
1.58{ }^{\circ} \mathrm{C} \text { (night) } \\
(3 \mathrm{~m})\end{array}$ & $\begin{array}{c}\text { Manchester, UK, IGR, } \\
\text { experimental study, } \\
\text { Results are of the undamaged roof. IGR } \\
\text { with perennial shrubs, influence of } \\
\text { damaged GR. }\end{array}$ \\
\hline Liang and Huang [127] & $\begin{array}{l}-1.09 \text { to } 2.00{ }^{\circ} \mathrm{C} \\
1 \mathrm{~m} \text { above }\end{array}$ & $\begin{array}{l}\text { Taiwan, IGR planted with a lawn, } \\
\text { experimental study, summer. }\end{array}$ \\
\hline $\begin{array}{l}\text { Pompeii II and } \\
\text { Hawkins [143] }\end{array}$ & $0.3^{\circ} \mathrm{C}$ & $\begin{array}{l}\text { Pennsylvania, USA, EGR, model-based } \\
\text { study, humid continental summertime. }\end{array}$ \\
\hline
\end{tabular}

\section{Human Thermal Comfort}

In terms of human thermal comfort, we selected studies showing indoor temperature reduction and a reduction in temperature at a pedestrian or street level. Table 9 shows that GRs reduce indoor temperatures up to $4.2^{\circ} \mathrm{C}$ depending on the diurnal weather conditions. The cooling is more significant during the day than at night. In some instances, at night, an increase in indoor temperature was observed due to the insulation provided by the GR $[116,143]$. This could be easily be solved by improving the natural ventilation in the building [114]. Additionally, selecting appropriate substrates and species other than sedum can also enhance the results.

Temperature reductions at the pedestrian level are not as pronounced as those observed at roof level. The temperature reductions range from 0.1 to $1.7^{\circ} \mathrm{C}$, mostly depending upon the type of GR (Table 10). Compared to EGRs, IGRs provide better pedestrian thermal comfort. The review suggests that the installation of GRs on low-rise buildings has a better impact on the reduction in temperature at the pedestrian level (see Table 10).

Jadaa et al. [145] reported a reduction of $12-14{ }^{\circ} \mathrm{C}$ in mean radiant temperature (MRT) on a hot summer day, and around $1-4{ }^{\circ} \mathrm{C}$ on a winter day after retrofitting GRs in a small neighborhood with low-to medium-rise buildings in the UAE. Installing an IGR is reported to reduce the physiological equivalent temperature (PET) by $10.9^{\circ} \mathrm{C}$ on a hot summer day [120]. The installation of an IGR on a building reportedly resulted in a reduction in the UTCI of $5.5^{\circ} \mathrm{C}[120]$.

Altogether, installing GRs improves human thermal comfort, though there can be slight warming observed during the night. Furthermore, there is only a limited impact of GRs on pedestrian thermal comfort, but this can be more significant in the case of low-rise buildings. 
Table 9. Indoor temperature reduction after implementing GRs, as reported in the selected studies.

\begin{tabular}{|c|c|c|}
\hline Authors & $\begin{array}{c}\text { Indoor Temperature } \\
\text { Reduction }\end{array}$ & Influencing Factors \\
\hline Fitchett et al. [118] & $\begin{array}{c}0.6^{\circ} \mathrm{C}-\text { mean difference } \\
5^{\circ} \mathrm{C}-\text { max difference } \\
-2{ }^{\circ} \mathrm{C}-\text { min difference }\end{array}$ & $\begin{array}{l}\text { South African region, EGR, } \\
\text { experimental study, dry } \\
\text { winter season. }\end{array}$ \\
\hline Scharf and Kraus [144] & 2.6 to $3.4{ }^{\circ} \mathrm{C}$ & $\begin{array}{l}\text { Antwerp, Belgium, two variants of } \\
\text { GR (dense green vs. sparse green), } \\
\text { building level study, hot summer } \\
\text { day. Dense green showed } \\
\text { better results. }\end{array}$ \\
\hline He et al. [116] & $\begin{array}{l}\text { Night }-2.5^{\circ} \mathrm{C} \text { higher } \\
\text { Day }-2{ }^{\circ} \mathrm{C} \text { lower }\end{array}$ & $\begin{array}{l}\text { Shanghai, China, EGR, experimental } \\
\text { study, north subtropical monsoon } \\
\text { climate, summer, soil water content, } \\
\text { solar radiation, and outdoor } \\
\text { temperature (longwave radiation). } \\
\text { Cooling effect more pronounced on } \\
\text { sunny days. Solar radiation } \\
\text { correlated the most with heat flux. } \\
\text { No difference when air conditioner } \\
\text { was applied. }\end{array}$ \\
\hline Lin et al. [113] & $\begin{array}{c}\text { Afternoon: } \\
\text { Taipei- } 1.0^{\circ} \mathrm{C} \text { to } 2.5^{\circ} \mathrm{C} \\
\text { Chiayi-1.6 }{ }^{\circ} \mathrm{C} \text { to } 4.2^{\circ} \mathrm{C} \\
\text { Night: } \\
\text { Taipei-0.7 to } 1.1^{\circ} \mathrm{C} \\
\text { Chiayi-0.9 }{ }^{\circ} \mathrm{C}\end{array}$ & $\begin{array}{l}\text { Taipei, Chiayi, Taiwan, EGR, } \\
\text { experimental study, rainfall, } \\
\text { different times of the day and } \\
\text { different climatic conditions. }\end{array}$ \\
\hline $\begin{array}{l}\text { Pompeii II and } \\
\text { Hawkins [143] }\end{array}$ & $\begin{array}{c}\text { Day-4.2 degrees cooler } \\
\text { Night- }-0.7 \text { degrees warmer }\end{array}$ & $\begin{array}{l}\text { Pennsylvania, USA, EGR, } \\
\text { model-based study, humid } \\
\text { continental summertime. }\end{array}$ \\
\hline Liang and Huang [127] & -0.90 to $4.2{ }^{\circ} \mathrm{C}$ & $\begin{array}{l}\text { Taiwan, IGR planted with a lawn, } \\
\text { experimental study, summer, lawn } \\
\text { plantation and external weather } \\
\text { conditions explored. }\end{array}$ \\
\hline
\end{tabular}

Table 10. Reduction in air temperature (pedestrian level), as reported in selected studies.

\begin{tabular}{|c|c|c|}
\hline Authors & $\begin{array}{c}\text { Reduction in Temperature at } \\
\text { Pedestrian Level }\end{array}$ & Influencing Factors \\
\hline Scharf and Kraus [144] & Improvement of 0.1 to $0.2^{\circ} \mathrm{C}$ & $\begin{array}{c}\text { Antwerp, Belgium, two variants of } \\
\text { GRs (dense green vs. sparse green), } \\
\text { building level study, } \\
\text { hot summer day. } \\
\text { Dense green showed better results. }\end{array}$ \\
\hline Lalošević et al. [137] & $\mathrm{EGR}-0.47, \mathrm{IGR}-1.51^{\circ} \mathrm{C}$ & $\begin{array}{l}\text { Belgrade, Serbia, IGR and EGR, } \\
\text { model-based study, a small } \\
\text { neighborhood was studied. } \\
\text { Height of the building influenced } \\
\text { the results. }\end{array}$ \\
\hline Peng and Jim [146] & $\begin{array}{l}\text { EGR-0.4 to } 0.7^{\circ} \mathrm{C} \text {, } \\
\text { IGR-0.5 to } 1.7^{\circ} \mathrm{C}\end{array}$ & $\begin{array}{l}\text { Hong Kong, IGR and EGRs, } \\
\text { subtropical ENVI-met model, } \\
\text { neighborhood study. } \\
\text { Maximum effect in } \\
\text { open-set low-rise sites. }\end{array}$ \\
\hline
\end{tabular}




\subsubsection{Air Quality}

We discuss the results from nine studies on GRs in the context of air quality. The studies primarily discuss the effect of GRs on the concentration of air pollutants such as $\mathrm{O}_{3}$ (ozone), $\mathrm{CO}_{2}$ (carbon dioxide), $\mathrm{SO}_{2}$ (sulfur dioxide), $\mathrm{NO}_{2}$ (nitrogen dioxide), $\mathrm{NO}$ (nitrogen oxide), and $\mathrm{PM}_{10}$ and $\mathrm{PM}_{2.5}$ particulate matters. Table 11 provides the details of the studies that focused on the effects of GRs on particular pollutants.

Table 11. Reduction in air pollutants according to the studies selected for review.

\begin{tabular}{|c|c|c|}
\hline Authors & Air Pollutants & Observations \\
\hline $\begin{array}{l}\text { Moghbel and Erfanian } \\
\text { Salim [147] }\end{array}$ & $\mathrm{CO}_{2}$ & $\begin{array}{l}\text { Reduction of around 20.71-27.98 ppm } \\
\text { (parts-per-million) per day. } \\
\text { Highest early morning and late evening. }\end{array}$ \\
\hline Agra et al. [148] & $\mathrm{CO}_{2}$ & GR with sedum ediforne emitted $\mathrm{CO}_{2}$. \\
\hline Tong et al. [149] & $\mathrm{PM}_{2.5}$ & $\begin{array}{l}\text { Concentrations near the IGR ( } 26 \mathrm{~m} \text { height) } \\
\text { reduced up to } 7-33 \% \text { as compared to street } \\
\text { level because of less vertical mixing and } \\
\text { high wind shear induced by higher thermal } \\
\text { stability near the GR. }\end{array}$ \\
\hline Speak et al. [150] & $\mathrm{PM}_{10}$ & $\begin{array}{c}\text { Implementing GRs on all flat roofs ( } 50 \mathrm{ha}) \text { in } \\
\text { a city center ( } 326 \mathrm{ha} \text { ) was observed to } \\
\text { reduce around } 0.21 \text { tonnes }(2.3 \%) \text { of } \mathrm{PM}_{10} \\
\text { levels in a year. }\end{array}$ \\
\hline Vázquez Morales et al. [151] & $\mathrm{PM}_{10}, \mathrm{SO}_{2}$ & $\begin{array}{c}\mathrm{PM}_{10} \text { concentration was around } 8 \% \text { higher } \\
\text { than the WHO health standard during the } \\
\text { morning rush hours. } \mathrm{SO}_{2} \text { was slightly } \\
\text { greater than the WHO standards. Adverse } \\
\text { effects only lasted during the morning } \\
\text { rush hours. }\end{array}$ \\
\hline Ramasubramanian et al. [152] & & $\begin{array}{l}\text { Around } 0.25-1.8 \mu \mathrm{g} / \mathrm{m}^{3}(1.3 \%) \text { of } \mathrm{O}_{3} \\
\text { reduced within two days when a GR was } \\
\text { installed in the proximity of building } \\
\text { ventilation systems. }\end{array}$ \\
\hline Moradpour et al. [153] & $\mathrm{NO}, \mathrm{NO}_{2}, \mathrm{O}_{3}$ & $\begin{array}{l}\text { Reduction in the concentration of } \mathrm{NO} \text { and } \\
\mathrm{NO}_{2} \text { due to increase in LAD with the aspect } \\
\text { ratio } 2.0 \text { decreased. Concentrations of } \mathrm{O}_{3} \\
\text { increased within the canyon and } 1.5 \mathrm{~m} \\
\text { above the street for the same settings. }\end{array}$ \\
\hline Park et al. [154] & $\mathrm{O}_{3}$ & $\begin{array}{l}\text { Around } 25.9 \% \text { of } \mathrm{O}_{3} \text { was reduced near the } \\
\text { street due to } \mathrm{NO}-\mathrm{O}_{3} \text { reaction, resulting in } \\
\text { better air quality for pedestrians. }\end{array}$ \\
\hline
\end{tabular}

Based on the observations listed in Table 11, the installation of GRs leads to reducing the concentrations of air pollutants, depending upon various conditions. For instance, Moghbel and Erfanian Salim [147] observed $\mathrm{CO}_{2}$ absorption to be the highest during the early morning and late evening and the lowest during peak traffic hours. Similarly, during morning rush hours, $\mathrm{PM}_{10}$ and $\mathrm{SO}_{2}$ were also reported to be higher than the WHO standards [151]. Apart from this, Agra et al. [148] reported that the GRs with Sedum Sediforne added to the high $\mathrm{CO}_{2}$ concentrations in the city by emitting $\mathrm{CO}_{2}$. Regarding $\mathrm{PM}_{2.5}$, concentrations near the roof were reported to be reduced as compared to at street level. This was mainly attributed to less vertical mixing and high wind shear induced by higher thermal stability near the GR [149].

Concerning $\mathrm{O}_{3}$ reduction, large, continuous GRs on taller buildings perform better in reducing $\mathrm{O}_{3}$ near the rooftop [152]. Two more studies [153,154] analyzed $\mathrm{O}_{3}$ reduction within a street canyon. Park et al. [154] considered a street canyon with an aspect ratio 
(AR, height-to-width ratio, $\mathrm{H} / \mathrm{W}$ ) of 1.0. The study considered $\mathrm{NOx}-\mathrm{O}_{3}$ reactions and observed that $\mathrm{O}_{3}$ concentrations were dependent upon these reactions. For instance, $\mathrm{O}_{3}$ is low in the areas where NOx is high. Primary pollutants such as NOx (nitrogen oxides), VOCs (volatile organic compounds), and $\mathrm{CO}$ (carbon monoxide) were concentrated near the street, whereas $\mathrm{O}_{3}$ was found more in the region above the buildings. Roof cooling increased the in-canopy winds, which facilitated the incoming flow of cleaner air (with $\mathrm{O}_{3}$ and without primary pollutants) and the outgoing flow of more polluted air (with primary pollutants).

When the aspect ratio was varied along with the leaf area density (LAD) in a similar setup, Moradpour et al. [153] suggested that for lower aspect ratios, the concentrations of ozone are higher as compared to $\mathrm{H} / \mathrm{W}=2.0$. The difference can be attributed to the structure of the flow, where $\mathrm{H} / \mathrm{W}=2.0$ contained two vertically aligned vortices, and scenarios with $\mathrm{H} / \mathrm{W} \leq 1$ contained one clockwise vortex. Thus, the authors suggested that the GRs are more useful for deep street canyons.

Similar to the previous studies, Baik et al. [155] also assessed the impact of GRs in an urban street canyon; however, the pollutants were considered to be non-reactive. A similar result was obtained where the cooling from the GRs flowed into the street canyon, resulting in a strengthened canyon flow, which enhanced the pollutant dispersion near the road, thereby decreasing the pollutant concentration and improving air quality at a pedestrian level. However, the authors pointed out that the degree of air quality improvement near the roads depended upon the ambient wind direction. This phenomenon stands true in the case of Moradpour et al. [153] and Park et al. [154] as well, especially in the case of NOx concentrations as their movement is initiated due to the cooling offered by GRs. One should note that these three studies incorporated primary urban morphologies with simplified street canyon aspect ratios. Moreover, as observed in the study by Tong et al. [149], where an existing GR was used, the pollutant concentrations at street level did not reduce as much. Moreover, in reality, the aspect ratios in urban environments are complex, and buildings in a canyon are of different heights. Altogether, the evidence suggests that GRs have the potential to reduce toxic pollutants when implemented at a large scale, suggesting a positive impact on air quality.

\subsubsection{Social Preference and Acceptance}

We found around 17 studies discussing the opinions of various stakeholders, such as architects, engineers, property developers, students, and common people, who are potentially the ones to implement and utilize GRs. Figure 4 represents the benefits perceived by stakeholders such as residents and professionals such as architects, engineers, and technical experts. Two studies considered in the review discussed the perception of residents, whereas five studies were observed to discuss the perception of professionals in the field.

Despite the perceived benefits, there are also some factors hindering the acceptance of GRs among stakeholders (Figure 5). Most studies suggest the initial construction costs, maintenance costs, and lack of awareness to be the main hindrances for the widespread acceptance of GRs. Moreover, the lack of knowledge and skilled labor for implementation and the lack of government incentives are additional concerns.

Acceptance of GRs among common people is related to their socio-economic backgrounds such as age, income, education level, attitude towards environmental issues, and social norms. For instance, L. Zhang et al. [161] observed that people with higher education and income and with an interest in environmental issues favor GRs. FernandezCañero et al. [162] also identified age as a parameter, wherein younger people proactively support the development of GRs in cities. Social norms-for instance, support from social networks, i.e., amongst family and friends, for investment in green initiatives-were also identified as one of the parameters for considering GR adoption. Furthermore, a perceived difficulty in being environmentally advanced, i.e., the non-availability of sufficient time and resources to adopt GRs, also plays a vital role in the adoption of GRs. Thus, for the adoption 
of GRs, it is vital to not only increase awareness but also to reduce the costs associated with GRs. Apart from this, Fernandez-Cañero et al. [162] have also pointed out the importance of the type of housing where people reside for the adoption of GRs. For instance, it is easier to install a GR on a privately owned house rather than on a rented apartment.

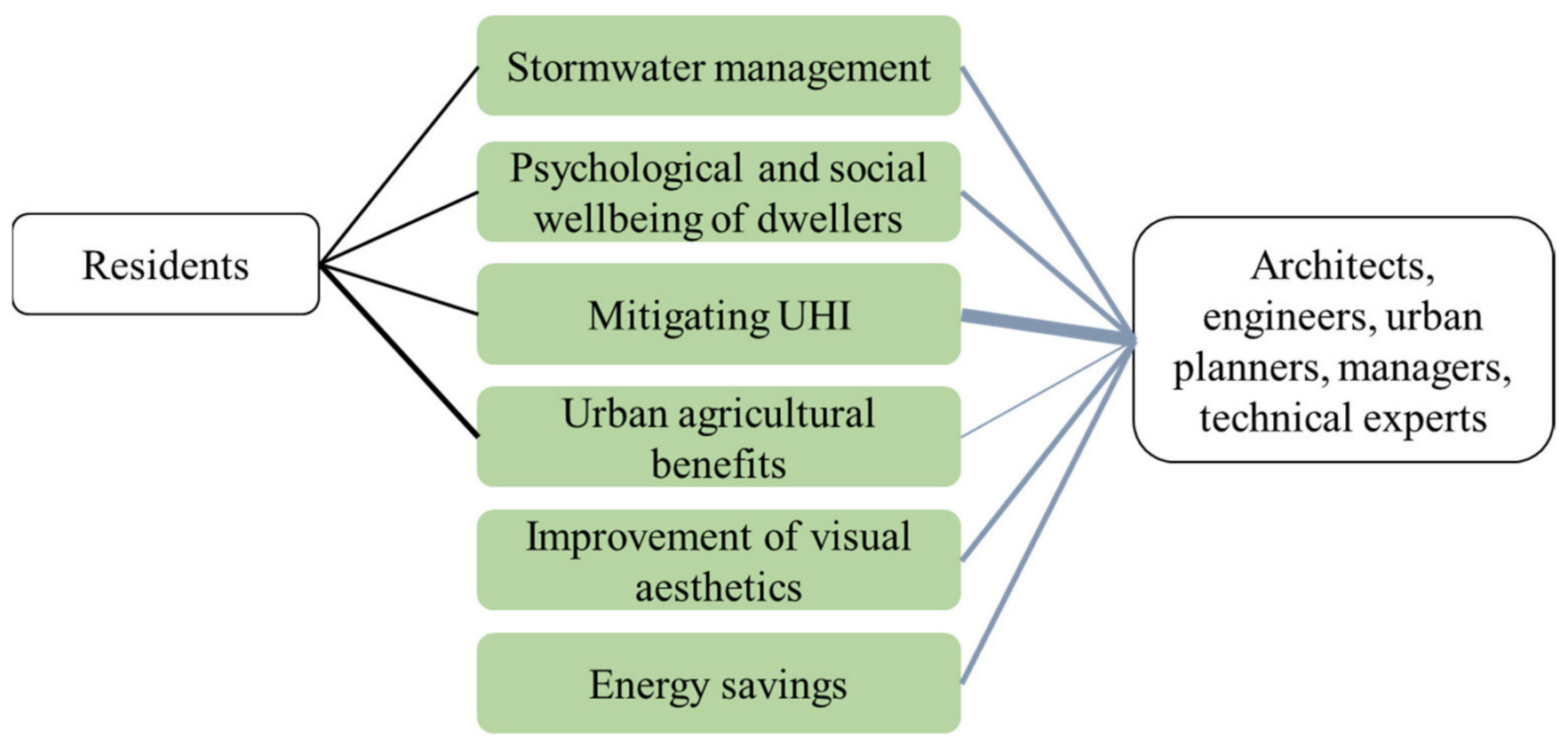

Figure 4. Schematic representing benefits of GRs as perceived by stakeholders. The thickness of the line represents the number of studies pointing out a particular benefit perceived by a group of stakeholders. (Resident perceptions reported by Nadal et al. [156] and Kim et al. [157]; perceptions of architects, urban planners, and others reported by Tabatabaee et al. [158], Sangkakool et al. [11], Tam et al. [159], and Rezvani et al. [160]).

The visual appearance and aesthetics of GRs play an essential role in their adoption by urbanites [163-165]. Perceptions based on experience and expectations and accessibility also play a crucial role in the demand for and favor of GRs. Loder [166] observed that the participants' previous experiences of nature and of narratives about native habitats mediated their perceptions of GRs in a central business district. For instance, prairiestyle vegetated GRs are found beautiful by the people of Chicago due to their previous experiences with areas outside of Chicago. In contrast, people in Toronto view real nature as forests and lakes. Thus, although they considered prairie-style GRs beautiful, they did not relate them to nature. Loder [166] also reported that the expectation of daily life experience plays an important role. The GR space could be optimized to mimic the memories of natural experiences, depending upon the visual or physical access demands as per the employees in the business districts. Along this line, Mesimäki et al. [167] observed that GRs provide experiential and recreational benefits. The authors' findings indicated that even a small but aesthetic accessible GR has the potential to offer a moment of respite in the middle of strenuous urban life [167].

Our review suggests that society prefers GRs, and there is the potential for the social acceptance of GRs if they have an affordable and aesthetically pleasing design. Additionally, user-specific experiences and expectations are essential to consider. Furthermore, there is a need for awareness programs related to the benefits of GRs to increase their outreach.

\subsubsection{Feasibility of GRs}

In this section, we discuss the findings from our review related to the feasibility of GRs, in terms of financial, economic, social, and environmental aspects. We short-listed ten studies that discuss the feasibility of GRs with the inclusion of several costs and benefits. 
We also found three other studies discussing GRs in terms of private and public costs and benefits.

Table 13 presents the types of costs and benefits considered in each of the studies. In the table, the review suggests that most studies consider only a few aspects of feasibility; however, some studies consider a wide range of costs and benefits which might increase their relevance and greatly influence the conclusions drawn. Table 12 presents the lifespan, scale, and city studied along with the key results in terms of the method chosen for the feasibility analysis. There are different methods used to study feasibility, for instance, benefit-cost ratio (BCR), net present value (NPV), life cycle costing (LCC), and payback period (PBP).

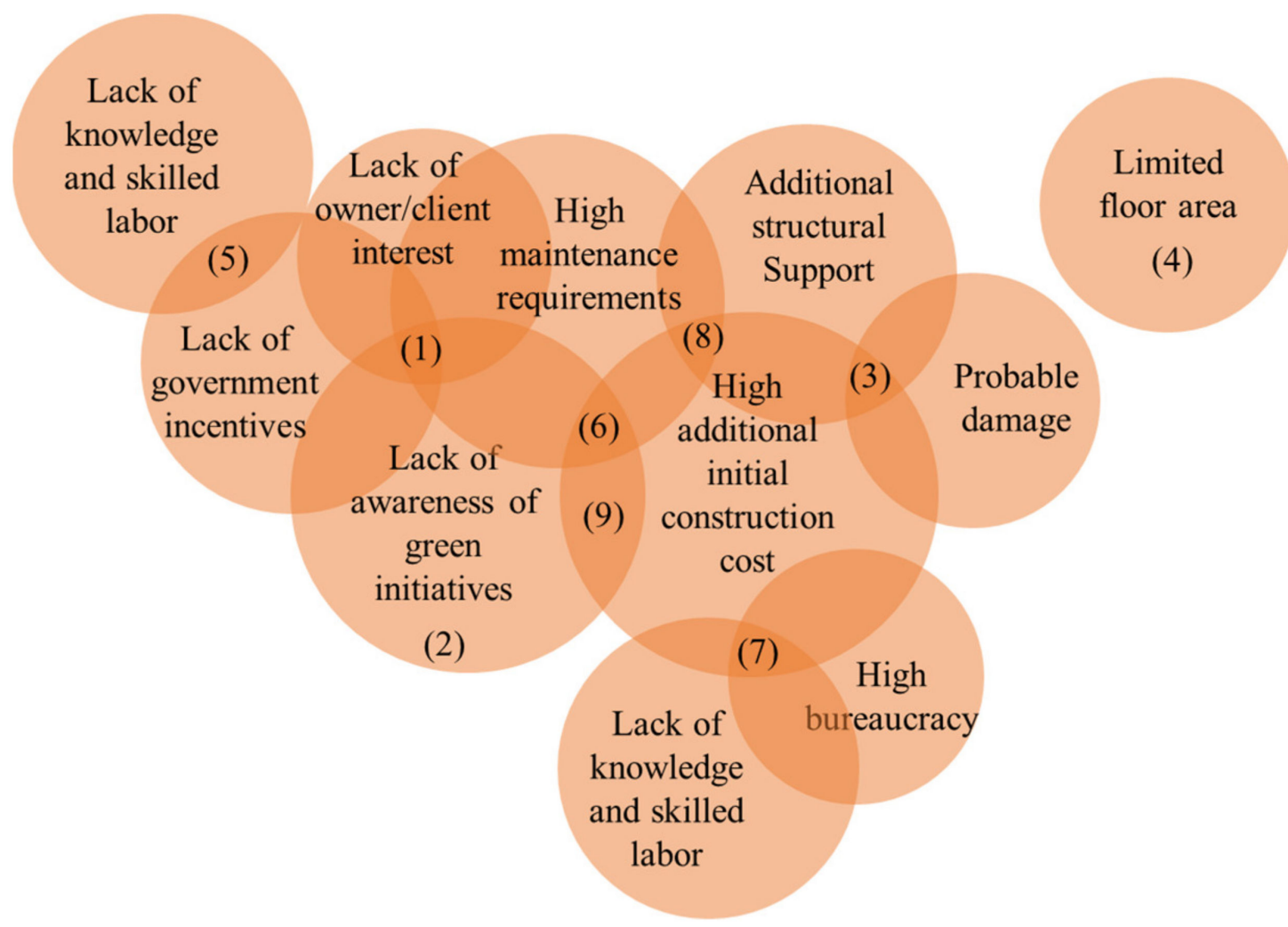

Figure 5. A Venn diagram representing the hindrances observed in studies on the adoption of GRs. The numbers in the unions of circles denote the studies that report the hindrances. (Hossain et al. [168] - 1 (architects/engineers/managers); Everett and Lamond [169]—2 (owners/occupiers); Tabatabaee et al. [158]—3 (architects/engineers/managers); Nadal et al. [156]—4 (residents, govt. officials, and technical experts); Sangkakool et al. [11]—5 (experts on GRs); Shams et al. [170]—6 (common people); Briz-de-Felipe and de Felipe-Boente [171]—7 (residents); Tam et al. [159]—8 (architects, engineers); Maryanti et al. [172]—9 (property developers)).

Among the selected studies, Teotónio et al. [173] incorporated the most types of costs and benefits in their analysis. This study was done only for commercial and residential buildings in Lisbon at financial, economic, and socio-environmental levels. Socioenvironmental benefits were the highest, followed by economic benefits, which included the increase in property value. The financial NPV was negative, given the high installation and maintenance costs. Considering all levels, the benefits were greater than the costs. The study also suggested that IGRs, though they have high costs, have more benefits than EGRs, one of which is the increase in recreational value.

Other studies have considered comparatively fewer benefits than Teotónio et al. [173]. Most of the studies have a BCR greater than one and an NPV greater than zero. However, Ziogou et al. [174], Ziogou et al. [175], and Shin and Kim [176] reported that the benefits of GRs are almost equal to or less than the costs. The primary reason for this is the initial 
installation cost of a GR. The cost of GRs varies depending upon the municipalities and the types of costs considered. One possible reason could also be the consideration of limited benefits. It should be noted that it is complex to measure all the benefits of GRs in monetary terms. If only the widespread benefits such as energy savings, emission reductions, and stormwater management were considered, the feasibility of GRs would be debatable. However, when more benefits are considered in the analysis, GRs appear to be more feasible.

Until now, we classified the benefits in terms of social, financial, economic, and environmental aspects. However, analysts often consider the benefits in terms of private and public as this clarifies the concerns of private developers and the government [27]. The private benefits, availed by private investors, cover the increased life span of the roof cover, the reduction in seasonal energy consumption, the added aesthetics of GRs, noise reduction, and the increase in property value. At times, additional subsidies provided for the adoption of GRs are also categorized as private benefits [177]. The public or social benefits include improvement in the UHI effect, the betterment of stormwater quality, reduced GHG emissions, and enhanced biodiversity [178]. Although the overall benefits of GRs exceed the costs, it is essential to understand if there are benefits at a private level, as this is what decides the adoption of GRs. Claus and Rousseau [27] observed that without government subsidies, the costs are higher than the benefits at the private level. However, providing subsidies might be costlier to the municipality if GRs are not offering enough benefits at a city scale. Mullen et al. [178] observed that the subsidies reduced the NPV at the public level. The increase in the property value can increase the private benefits more than the costs even without the provision of subsidies [177].

Overall, the evidence suggests that the implementation of GRs is feasible in most aspects, even at private and public levels, considering all the benefits of GRs in the analysis. However, more studies are needed that incorporate the benefits of GRs in a comprehensive manner and at different levels, which elaborate the benefits for the involved stakeholders.

Table 12. Results from various feasibility studies.

\begin{tabular}{ccccc}
\hline Authors & Scale & City & $\begin{array}{c}\text { Lifespan } \\
\text { (Years) }\end{array}$ & Results \\
\hline Shin and Kim [179] & Municipality & $\begin{array}{c}\text { Jung Su, Seoul, South } \\
\text { Korea }\end{array}$ & 20 & BCR $=1.174$ \\
\hline Cascone et al. [180] & Building & Catania, Italy & 20 & NPV $=35.6-1815.3$ Euros \\
\hline Ziogou et al. [174] & Urban residential area & Cyprus & 30 & $\begin{array}{c}\text { LCC higher than a } \\
\text { conventional roof }\end{array}$ \\
\hline Teotónio et al. [173] & $\begin{array}{c}\text { Commercial and } \\
\text { residential buildings }\end{array}$ & Lisbon, Portugal & 40 & $\begin{array}{c}\text { Social NPV }=320 \text { million } \\
\text { euros } / 10.375 \text { roofs }\end{array}$ \\
\hline Foudi et al. [181] & $\begin{array}{c}\text { Commercial and } \\
\text { residential buildings }\end{array}$ & Madrid, Spain & 79 & BCR $=0.02-2.18$ \\
\hline Ziogou et al. [175] & Building & Cyprus & 20 & $\begin{array}{c}\text { NPV smaller than } \\
\text { normal roof NPV }<0\end{array}$ \\
\hline Mahmoud et al. [182] & Building & Saudi Arabia & 40 & NPV $>0$ after 20 years \\
\hline Mahdiyar et al. [177] & Building & Kuala Lumpur, Malaysia & 20 & 3 and 5 years for ext and \\
int roofs
\end{tabular}


Table 13. Types of costs and benefits considered in feasibility studies.

\begin{tabular}{|c|c|c|c|c|c|c|c|c|c|c|c|}
\hline \multirow{2}{*}{\multicolumn{2}{|c|}{ Cost/Benefits }} & \multicolumn{10}{|c|}{ Studies } \\
\hline & & $\begin{array}{c}\text { Shin and Kim } \\
\text { [179] }\end{array}$ & $\begin{array}{c}\text { Cascone et al. } \\
\text { [180] }\end{array}$ & $\begin{array}{c}\text { Ziogou et al. } \\
\text { [174] }\end{array}$ & $\begin{array}{c}\text { Teotónio et al. } \\
\text { [173] }\end{array}$ & $\begin{array}{c}\text { Foudi et al. } \\
\text { [181] }\end{array}$ & $\begin{array}{c}\text { Ziogou et al. } \\
\text { [175] }\end{array}$ & $\begin{array}{l}\text { Mahmoud } \\
\text { et al. [182] }\end{array}$ & $\underset{\text { [177] }}{\text { Mahdiyar et al. }}$ & $\begin{array}{c}\text { Peng and Jim } \\
\text { [21] }\end{array}$ & $\begin{array}{c}\text { Shin and Kim } \\
{[176]}\end{array}$ \\
\hline \multirow{3}{*}{ Costs } & Structural safety & $\checkmark$ & & & & & & & & & $\checkmark$ \\
\hline & $\begin{array}{c}\text { Operational and } \\
\text { Maintenance }\end{array}$ & $\checkmark$ & $\checkmark$ & & $\checkmark$ & $\checkmark$ & $\checkmark$ & $\checkmark$ & $\checkmark$ & $\checkmark$ & $\checkmark$ \\
\hline & Environmental & $\checkmark$ & & & $\checkmark$ & & & & & & \\
\hline \multirow{5}{*}{$\begin{array}{c}\text { Environmental } \\
\text { benefits }\end{array}$} & Air Pollutant removal & $\checkmark$ & $\checkmark$ & & $\checkmark$ & & & $\checkmark$ & & $\checkmark$ & $\checkmark$ \\
\hline & Carbon footprint reduction & & & & & $\checkmark$ & & & & & \\
\hline & Biodiversity & & & & $\checkmark$ & & & $\checkmark$ & & & \\
\hline & UHI mitigation & $\checkmark$ & $\checkmark$ & $\checkmark$ & $\checkmark$ & $\checkmark$ & $\checkmark$ & $\checkmark$ & $\checkmark$ & $\checkmark$ & $\checkmark$ \\
\hline & Health benefits & $\checkmark$ & & & & $\checkmark$ & & & & & \\
\hline \multirow{2}{*}{ Financial benefits } & Tax incentive & & $\checkmark$ & & & & & & & & \\
\hline & Inflation and discount rates & & & & $\checkmark$ & & & & $\checkmark$ & & \\
\hline \multirow{2}{*}{ Economic benefits } & Property value & & & & & & & & $\checkmark$ & & \\
\hline & $\begin{array}{l}\text { Urban aesthetics } \\
\text { and comfort }\end{array}$ & $\checkmark$ & & & & & & & & & \\
\hline \multirow{2}{*}{ Other } & Rooftop lifespan increasing & $\checkmark$ & & & & & & & $\checkmark$ & & $\checkmark$ \\
\hline & Urban rooftop farming & & & & $\checkmark$ & & & & & & \\
\hline
\end{tabular}




\section{Discussion}

\subsection{Quantity of Available Literature}

The paper reviewed a total of 158 papers, which were identified using a systematic search strategy. Based on the selection criteria, the documentation (number of research articles) on GRs' contribution to each ecosystem service varied significantly (Figure 2). According to our review, the GRs' contributions to water management (61 studies) and UHI (39 studies) were more widely studied than the other aspects. The aspect of GRs' contribution to the improvement of air quality appears to be limited. Apart from this, most studies selected in this review were carried out at a building level. There were a few studies that were done at a city and neighborhood level in terms of water management, UHI, and feasibility. However, more studies at a larger scale for other aspects such as biodiversity and air quality can boost motivation for the integration of GRs into urban areas.

\subsection{Current Status and Challenges}

This section discusses the reviewed evidence and identifies the challenges of incorporating GRs into urban areas.

Regarding the impact on biodiversity, the review suggests that GRs on buildings with lower heights have been observed to support species in a better way [50]. Given that urban areas are densifying and becoming more compact, cities are predicted to grow vertically. Thus, the height of buildings is an essential parameter for analyzing GRs' impact on biodiversity. In the review, we did not find enough studies in the literature on the effect of height on GRs' impact on biodiversity. We found only two studies where Braaker et al. [50] considered buildings of $15 \mathrm{~m}$ or less and Wang et al. [40] considered a $50 \mathrm{~m}$ tall roof garden. We need more studies analyzing the impact of building height on GR biodiversity.

Similarly, there is a paucity in the literature on GRs' role in ecological connectivity. We found that only Braaker et al. [50] and Joimel et al. [47] considered this aspect to any extent. As GRs are considered to be a substitute for green areas on the ground, they are supposed to facilitate the movement of organisms through urban landscapes [183]. Therefore, more evidence is needed to understand the role of GRs in strengthening ecological networks at an agglomeration scale. Apart from this, our review also pointed out a concern in terms of mosquito abundance on GRs [36], which can have an effect on the health of people, especially in dense urban areas.

Our review suggests that GRs aid in water management, owing to their high water retention potential. However, the retention is high only for low- to moderate-intensity rainfall. Furthermore, GRs can be one of the factors in avoiding flood-like conditions. Still, other solutions might be needed in case of extreme rainfall. The review also suggested that the runoff from GRs also acts as a source of phosphorus in the case of most commercial substrates, which can pollute water resources. The concentration of pollutants in EGRs is lower than in IGRs due to the existence of fertilizers in IGRs. Alternative substrates and vegetation types were also observed to reduce the concentrations of nutrients or metals.

Regarding UHI mitigation, our review suggests that GRs have a limited impact on pedestrian thermal comfort. A significant impact can only be found with low-rise buildings. Building height has an influence on the impact of GRs on the temperature at street level. Besides, urban morphology is observed to play an important role in temperature regulation [184]. The performance of GRs may also vary depending upon the urban morphology of a block and its surroundings. This should be further analyzed in future studies.

Apart from this, our review suggests that GRs substantially reduce roof surface temperatures compared to bare roofs. Additionally, we observed that most studies reported significant reductions in energy demand and consumption due to a decrease in cooling loads. Heating load reductions were also observed in cases where appropriate substrates, thermal insulation, and plant species were used. However, these effects are prominent only on the top floors. GRs also decrease the indoor temperature of a building. However, slight warming can be experienced during the night. It should be noted that the maintenance of GRs is important for the desired benefits, especially in extreme weather. 
Regarding the impact on air quality, our review suggests that GRs reduce the concentrations of pollutants in the air near the GR. The literature on the improvement in the air quality near the street also shows a positive impact on air quality. However, the urban morphology used in the models for air quality was quite simplified, and the results might vary in reality due to more complex morphologies.

In terms of social preference and acceptance, our review suggests that GRs with lowcost and high aesthetic value are in demand. Moreover, our review suggests that hindrances such as high costs and maintenance and lack of knowledge often affect GRs' acceptability in urban areas. In the feasibility studies, high installation costs were considered as a barrier at the private level, suggesting the need for subsidies. Apart from this, the adoption of GRs also depends on the type of housing. For instance, the UHI benefits such as energy savings are mainly reported to be significant at top floors and negligible elsewhere. Ergo, it can be challenging to get the approval of all residents of a multi-story building, given that the benefits are unevenly distributed.

Concerning social preference, most studies considered well-maintained GRs, which are effectively green, for understanding users' perspectives. However, due to extreme weather conditions in some regions, the vegetation during the months of winter or summer can be brown and dry, resulting in a different opinion of users. More extensive studies are required to study the social acceptability of GRs during the dry months when vegetation is dried.

In the review, we observed that the social benefits in the feasibility analyses were only considered in terms of public health, but the impact of GRs on social cohesion/inclusion was not considered. Greening strategies, at times, tend to increase property prices and result in gentrification and the marginalization of the poor [185]. More studies are needed to understand the social impact of GRs at the neighborhood scale.

\subsection{Future Perspectives}

This section discusses the future perspectives for research into the urban integration of GRs. The future perspectives in terms of further research are as follows:

- Regarding biodiversity, future studies should consider taller buildings while analyzing GRs' impact on urban biodiversity. Moreover, the studies analyzing the role of GRs in ecological connectivity need to consider the height of buildings. Future research should also focus on mainstreaming GRs in a city-scale habitat network analysis to connect existing ecological areas.

- Regarding water management, as runoff water quality from GRs is a concern, according to our review, further studies should focus on how the runoff from GRs can affect surface water sources and urban water management.

- In terms of UHI mitigation, as the urban morphology of a neighborhood can be a contributing factor in the impact of GRs on pedestrian thermal comfort, future research should include urban morphological parameters in the study to understand the effect of GRs on pedestrian thermal comfort in a better way.

- Concerning air quality, further research should involve more realistic morphologies while analyzing the impact of GRs on air quality. Additionally, more studies at a large scale would enhance the level of evidence for the impact of GRs on air quality.

- Regarding social acceptability, low-cost GRs are essential for better integration into urban areas. Nevertheless, the aesthetic value of GRs also can boost their implementation. To understand the acceptability of GRs, further research should focus on considering the temporal cycles on vegetation while observing users' perspectives.

- Regarding feasibility, the cost of GRs is one of the concerns. While subsidies may be one of the solutions, research for identifying the affordable components of GRs can pave the way for large-scale adaptability.

- Further research should focus on GRs' social impact, especially on property prices and the subsequent possibility of gentrification. 


\section{Conclusions}

This paper systematically and comprehensively reviewed the recent literature on GRs to identify the challenges and perspectives related to the urban integration of green roofs. Our review suggests that GRs have the potential to deliver multiple ecosystem services at the same time. GRs are the most useful tool considering the rapid increment in the built-up and lowered availability of open spaces for intensive green infrastructure. However, the effectiveness of GRs in delivering ecosystem services is largely dependent on context-specific parameters, such as weather conditions and existing construction or design-related parameters. Integrating GRs into urban areas can be challenging given the diversity of actors, functions, and conditions characterizing these areas. Although significant research has already been done on GRs, there is a need for more evidence covering more geographical locations and contexts. Firstly, the review pointed out the need for including future urbanization scenarios such as tall buildings while analyzing the impact of GRs on ecological networks. Secondly, the quality of runoff from GRs remains a concern. Further research is needed on how this runoff can affect surface water sources and urban water management. Regarding UHI mitigation, the review emphasized the inclusion of urban morphological parameters alongside future analyses of the impact of GRs, as morphology plays a vital role in microclimate regulation. Similarly, considering realistic urban morphologies is necessary for analyzing the impact of GRs on air quality. In terms of social acceptance, our review points out the need to consider the temporal cycles of vegetation while noting the perspective of users. Additionally, further research on the social impact of GRs is needed, considering their influence on property prices. Lastly, the review stresses the need for more city-scale studies on the impact of GRs on ecosystem services, especially in terms of biodiversity and air quality.

Author Contributions: Conceptualization, M.Y.J. and J.T.; methodology, M.Y.J. and J.T.; formal analysis, M.Y.J.; writing—original draft preparation, M.Y.J.; writing—review and editing, M.Y.J. and J.T.; revisions, M.Y.J. and J.T.; supervision, J.T.; project administration, J.T.; funding acquisition, J.T. All authors have read and agreed to the published version of the manuscript.

Funding: The research was funded through the ARC grant for Concerted Research Actions for project number 19/23-28 "CityRoof" financed by the French Community of Belgium (WalloniaBrussels Federation).

Institutional Review Board Statement: Not applicable.

Informed Consent Statement: Not applicable.

Data Availability Statement: Not applicable.

Conflicts of Interest: The authors declare no conflict of interest.

\section{References}

1. Bibri, S.E.; Krogstie, J. Smart sustainable cities of the future: An extensive interdisciplinary literature review. Sustain. Cities Soc. 2017, 31, 183-212. [CrossRef]

2. UN-Habitat. State of the World's Cities 2012/2013: Prosperity of Cities. 2012. Available online: https://unhabitat.org/books/pr osperity-of-cities-state-of-the-worlds-cities-20122013/ (accessed on 28 April 2020).

3. UNDP. Goal 11: Sustainable Cities and Communities. 2016. Available online: https://www.undp.org/content/undp/en/home/ sustainable-development-goals / goal-11-sustainable-cities-and-communities.html (accessed on 12 March 2020).

4. Gómez-Baggethun, E.; Barton, D.N. Classifying and valuing ecosystem services for urban planning. Ecol. Econ. 2013, 86, 235-245. [CrossRef]

5. Oh, K.; Lee, D.; Park, C. Urban Ecological Network Planning for Sustainable Landscape Management. J. Urban Technol. 2011, 18, 39-59. [CrossRef]

6. Cuce, E. Thermal regulation impact of green walls: An experimental and numerical investigation. Appl. Energy 2017, 194, 247-254. [CrossRef]

7. Stone, B. Urban sprawl and air quality in large US cities. J. Environ. Manag. 2008, 86, 688-698. [CrossRef]

8. Herrera-Gomez, S.S.; Quevedo-Nolasco, A.; Pérez-Urrestarazu, L. The role of green roofs in climate change mitigation. A case study in Seville (Spain). Build. Environ. 2017, 123, 575-584. [CrossRef] 
9. Akbari, H.; Menon, S.; Rosenfeld, A. Global cooling: Increasing world-wide urban albedos to offset $\mathrm{CO}_{2}$. Clim. Chang. 2009, 94, 275-286. [CrossRef]

10. Liu, W.; Wei, W.; Chen, W.; Deo, R. The impacts of substrate and vegetation on stormwater runoff quality from extensive green roofs. J. Hydrol. 2019, 576, 575-582. [CrossRef]

11. Sangkakool, T.; Techato, K.; Zaman, R.; Bruderman, T. Prospects of green roofs in urban Thailand-A multi-criteria decision analysis. J. Clean. Prod. 2018, 196, 400-410. [CrossRef]

12. Shafique, M.; Kim, R.; Rafiq, M. Green roof benefits, opportunities and challenges-A review. Renew. Sustain. Energy Rev. 2018, 90, 757-773. [CrossRef]

13. Zhang, X.; Shen, L.; Tam, V.W.Y.; Lee, W. Barriers to implement extensive green roof systems: A Hong Kong study. Renew. Sustain. Energy Rev. 2012, 16, 314-319. [CrossRef]

14. Mahdiyar, A.; Tabatabaee, S.; Abdullah, A.; Marto, A. Identifying and assessing the critical criteria affecting decision-making for green roof type selection. Sustain. Cities Soc. 2018, 39, 772-783. [CrossRef]

15. Oberndorfer, E.; Lundholm, J.; Bass, B.; Coffeman, R.; Doshi, H.; Dunnett, N.; Gaffin, S.; Kohler, M.; Liu, K.; Rowe, B. Green Roofs as Urban Ecosystems: Ecological Structures, Functions, and Services. Bioscience 2007, 57, 823-833. [CrossRef]

16. Bonoli, A.; Conte, A.; Maglionico, M.; Stojvok, I. Green roofs for sustainable water management in urban areas. Environ. Eng. Manag. J. 2013, 12, 153-156.

17. Tsantopoulos, G.; Varras, G.; Chiotelli, E.; Fotia, K.; Batou, M. Public perceptions and attitudes toward green infrastructure on buildings: The case of the metropolitan area of Athens, Greece. Urban For. Urban Green. 2018, 34, 181-195. [CrossRef]

18. Getter, K.L.; Rowe, D.B. The role of extensive green roofs in sustainable development. HortScience 2006, 41, 1276-1285. [CrossRef]

19. Peri, G.; Traverso, M.; Finkbeiner, M.; Rizzo, G. The cost of green roofs disposal in a life cycle perspective: Covering the gap. Energy 2012, 48, 406-414. [CrossRef]

20. Williams, N.S.G.; Rayner, J.P.; Raynor, K.J. Green roofs for a wide brown land: Opportunities and barriers for rooftop greening in Australia. Urban For. Urban Green. 2010, 9, 245-251. [CrossRef]

21. Peng, L.L.H.; Jim, C.Y. Economic evaluation of green-roof environmental benefits in the context of climate change: The case of Hong Kong. Urban For. Urban Green. 2015, 14, 554-561. [CrossRef]

22. Kosareo, L.; Ries, R. Comparative environmental life cycle assessment of green roofs. Build. Environ. 2007, 42, 2606-2613. [CrossRef]

23. Jasionkowski, R.; Lewandowska-Czarnecka, A. The potential of urban agriculture for sustainability of cities in Poland. Ecol. Quest. 2016, 24, 59-64. [CrossRef]

24. Nardini, A.; Andri, S.; Crasso, M. Influence of substrate depth and vegetation type on temperature and water runoff mitigation by extensive green roofs: Shrubs versus herbaceous plants. Urban Ecosyst. 2012, 15, 697-708. [CrossRef]

25. Berardi, U.; GhaffarianHoseini, A.; GhaffarianHoseini, A. State-of-the-art analysis of the environmental benefits of green roofs. Appl. Energy 2014, 115, 411-428. [CrossRef]

26. Gargari, C.; Bibbiani, C.; Fantozzi, F.; Campitti, C. Environmental Impact of Green Roofing: The Contribute of a Green Roof to the Sustainable use of Natural Resources in a Life Cycle Approach. Agric. Agric. Sci. Procedia 2016, 8, 646-656. [CrossRef]

27. Claus, K.; Rousseau, S. Public versus private incentives to invest in green roofs: A cost benefit analysis for Flanders. Urban For. Urban Green. 2012, 11, 417-425. [CrossRef]

28. Carter, T.; Fowler, L. Establishing green roof infrastructure through environmental policy instruments. Environ. Manag. 2008, 42, 151-164. [CrossRef] [PubMed]

29. Langemeyer, J.; Wedgwood, D.; McPhearson, T. Creating urban green infrastructure where it is needed-A spatial ecosystem service-based decision analysis of green roofs in Barcelona. Sci. Total Environ. 2020, 707, 135487. [CrossRef] [PubMed]

30. Sodiq, A.; Baloch, A.A.B.; Khan, S.A.N. Towards modern sustainable cities: Review of sustainability principles and trends. J. Clean. Prod. 2019, 227, 972-1001. [CrossRef]

31. Jabareen, Y.R. Sustainable urban forms: Their typologies, models, and concepts. J. Plan. Educ. Res. 2006, 26, 38-52. [CrossRef]

32. Jenks, M.; Jones, C. Dimensions of the Sustainable City; Springer: Dordrecht, The Netherlands, 2010; Available online: https: / /link.springer.com/book/10.1007\%2F978-1-4020-8647-2 (accessed on 19 May 2020).

33. Goddard, M.A.; Dougill, A.J.; Benton, T.G. Scaling up from gardens: Biodiversity conservation in urban environments. Trends Ecol. Evol. 2010, 25, 90-98. [CrossRef]

34. James, P.; Tzoulas, K.; Adams, M.D.; Barber, A.; Box, J.; Breuste, J.; Elmqvist, T.; Frith, M.; Gordon, C.; Greening, J.; et al. Towards an integrated understanding of green space in the European built environment. Urban For. Urban Green. 2009, 8, 65-75. [CrossRef]

35. Francis, F.M.; Jensen, M.B. Benefits of green roofs: A systematic review of the evidence for three ecosystem services. Urban For. Urban Green. 2017, 28, 167-176. [CrossRef]

36. Wong, G.K.L.; Jim, C.Y. Do vegetated rooftops attract more mosquitoes? Monitoring disease vector abundance on urban green roofs. Sci. Total Environ. 2016, 573, 222-232. [CrossRef]

37. Washburn, B.E.; Swearingin, R.M.; Pullins, C.K.; Rice, M.E. Composition and Diversity of Avian Communities Using a New Urban Habitat: Green Roofs. Environ. Manag. 2016, 57, 1230-1239. [CrossRef] [PubMed]

38. Partridge, D.R.; Clark, J.A. Urban green roofs provide habitat for migrating and breeding birds and their arthropod prey. PLoS ONE 2018, 13, e0202298. [CrossRef] 
39. Deng, H.; Jim, C.Y. Spontaneous plant colonization and bird visits of tropical extensive green roof. Urban Ecosyst. 2017, 20, 337-352. [CrossRef]

40. Wang, J.W.; Poh, C.H.; Tan, C.Y.T.; Lee, V.N.; Jain, A.; Webb, E.L. Building biodiversity: Drivers of bird and butterfly diversity on tropical urban roof gardens. Ecosphere 2017, 8, e01905. [CrossRef]

41. Vasl, A.; Shalom, H.; Kadas, G.J.; Blaustein, L. Sedum-Annual plant interactions on green roofs: Facilitation, competition and exclusion. Ecol. Eng. 2017, 108, 318-329. [CrossRef]

42. Vandegrift, D.A.; Rowe, D.B.; Cregg, B.M.; Liang, D. Effect of substrate depth on plant community development on a Michigan green roof. Ecol. Eng. 2019, 138, 264-273. [CrossRef]

43. Pétremand, G.; Chittaro, Y.; Braaker, S.; Brenneisen, S.; Gerner, M.; Obrist, M.K.; Rochefort, S.; Szallies, A.; Moretti, M. Ground beetle (Coleoptera: Carabidae) communities on green roofs in Switzerland: Synthesis and perspectives. Urban Ecosyst. 2018, 21, 119-132. [CrossRef]

44. Madre, F.; Vergnes, A.; Machon, N.; Clergeau, P. A comparison of 3 types of green roof as habitats for arthropods. Ecol. Eng. 2013, 57, 109-117. [CrossRef]

45. Madre, F.; Vergnes, A.; Machon, N.; Clergeau, P. Green roofs as habitats for wild plant species in urban landscapes: First insights from a large-scale sampling. Landsc. Urban Plan. 2014, 122, 100-107. [CrossRef]

46. Kratschmer, S.; Kriechbaum, M.; Pachinger, B. Buzzing on top: Linking wild bee diversity, abundance and traits with green roof qualities. Urban Ecosyst. 2018, 21, 429-446. [CrossRef]

47. Joimel, S.; Grard, B.; Auclerc, A.; Hedde, M.; le Doaré, N.; Salmon, S.; Chenu, C. Are Collembola "flying" onto green roofs? Ecol. Eng. 2018, 111, 117-124. [CrossRef]

48. Ksiazek-Mikenas, K.; Fant, J.B.; Skogen, K.A. Pollinator-Mediated Gene Flow Connects Green Roof Populations Across the Urban Matrix: A Paternity Analysis of the Self-Compatible Forb Penstemon hirsutus. Front. Ecol. Evol. 2019, 7. [CrossRef]

49. McKinney, M.L.; Gladstone, N.S.; Lentz, J.G.; Jackson, F.A. Land snail dispersal, abundance and diversity on green roofs. PLoS ONE 2019, 14, e0221135. [CrossRef] [PubMed]

50. Braaker, S.; Obrist, M.K.; Ghazoul, J.; Moretti, M. Habitat connectivity and local conditions shape taxonomic and functional diversity of arthropods on green roofs. J. Anim. Ecol. 2017, 86, 521-531. [CrossRef] [PubMed]

51. Benvenuti, S. Wildflower green roofs for urban landscaping, ecological sustainability and biodiversity. Landsc. Urban Plan. 2014 124, 151-161. [CrossRef]

52. Rumble, H.; Gange, A.C. Soil microarthropod community dynamics in extensive green roofs. Ecol. Eng. 2013, 57, 197-204. [CrossRef]

53. Palermo, S.A.; Turco, M.; Principato, F.; Piro, P. Hydrological Effectiveness of an Extensive Green Roof in Mediterranean Climate. Water 2019, 11, 1378. [CrossRef]

54. Burszta-Adamiak, E.; Stańczyk, J.; Łomotowski, J. Hydrological performance of green roofs in the context of the meteorological factors during the 5-year monitoring period. Water Environ. J. 2019, 33, 144-154. [CrossRef]

55. Talebi, A.; Bagg, S.; Sleep, B.E.; O'Carroll, D.M. Water retention performance of green roof technology: A comparison of canadian climates. Ecol. Eng. 2019, 126,1-15. [CrossRef]

56. Liu, X.; Chui, T.F.M. Evaluation of Green Roof Performance in Mitigating the Impact of Extreme Storms. Water 2019, 11, 815. [CrossRef]

57. Sims, A.W.; Robinson, C.E.; Smart, C.C.; O'Carroll, D.M. Mechanisms controlling green roof peak flow rate attenuation. J. Hydrol. 2019, 577, 123972. [CrossRef]

58. Yin, H.; Kong, F.; Dronova, I. Hydrological performance of extensive green roofs in response to different rain events in a subtropical monsoon climate. Landsc. Ecol. Eng. 2019, 15, 297-313. [CrossRef]

59. Liu, W.; Feng, Q.; Chen, W.; Wei, W.; Deo, R.C. The influence of structural factors on stormwater runoff retention of extensive green roofs: New evidence from scale-based models and real experiments. J. Hydrol. 2019, 569, 230-238. [CrossRef]

60. Longobardi, A.; D’Ambrosio, R.; Mobilia, M. Predicting Stormwater Retention Capacity of Green Roofs: An Experimental Study of the Roles of Climate, Substrate Soil Moisture, and Drainage Layer Properties. Sustainability 2019, 11, 6956. [CrossRef]

61. Schultz, I.; Sailor, D.J.; Starry, O. Effects of substrate depth and precipitation characteristics on stormwater retention by two green roofs in Portland OR. J. Hydrol. Reg. Stud. 2018, 18, 110-118. [CrossRef]

62. Harada, Y.; Whitlow, T.H.; Walter, M.T.; Bassuk, N.L.; Russell-Anelli, J.; Schindelbeck, R.R. Hydrology of the Brooklyn Grange, an urban rooftop farm. Urban Ecosyst. 2018, 21, 673-689. [CrossRef]

63. Abualfaraj, N.; Cataldo, J.; Elborolosy, Y.; Fagan, D.; Woerdeman, S.; Carson, T.; Montalto, F. Monitoring and Modeling the Long-Term Rainfall-Runoff Response of the Jacob, K. Javits Center Green Roof. Water 2018, 10, 1494. [CrossRef]

64. Shafique, M.; Kim, R.; Kyung-Ho, K. Green Roof for Stormwater Management in a Highly Urbanized Area: The Case of Seoul, Korea. Sustainability 2018, 10, 584. [CrossRef]

65. Piro, P.; Carbone, M.; de Simone, M.; Maiolo, M.; Bevilacqua, P.; Arcuri, N. Energy and Hydraulic Performance of a Vegetated Roof in Sub-Mediterranean Climate. Sustainability 2018, 10, 3473. [CrossRef]

66. Viola, F.; Hellies, M.; Deidda, R. Retention performance of green roofs in representative climates worldwide. J. Hydrol. 2017, 553, 763-772. [CrossRef]

67. Cipolla, S.S.; Maglionico, M.; Stojkov, I. A long-term hydrological modelling of an extensive green roof by means of SWMM. Ecol. Eng. 2016, 95, 876-887. [CrossRef] 
68. Elliott, R.M.; Gibson, R.A.; Carson, T.B.; Marasco, D.E.; Culligan, P.J.; McGillis, W.R. Green roof seasonal variation: Comparison of the hydrologic behavior of a thick and a thin extensive system in New York City. Environ. Res. Lett. 2016, 11, 074020. [CrossRef]

69. Kok, K.H.; Sidek, L.M.; Chow, M.F.; Abidin, M.R.Z.; Basri, H.; Hayder, G. Evaluation of green roof performances for urban stormwater quantity and quality controls. Int. J. River Basin Manag. 2016, 14, 1-7. [CrossRef]

70. Sims, A.W.; Robinson, C.E.; Smart, C.C.; Voogt, J.A.; Hay, G.J.; Lundholm, J.T.; Powers, B.; O'Carroll, D.M. Retention performance of green roofs in three different climate regions. J. Hydrol. 2016, 542, 115-124. [CrossRef]

71. Sobczyk, M.; Mrowiec, M. Retention capacity of extensive green roofs. J. Water L Dev. 2016, 30, 113-117. [CrossRef]

72. Lee, J.Y.; Lee, M.J.; Han, M. A pilot study to evaluate runoff quantity from green roofs. J. Environ. Manag. 2015, 152, 171-176. [CrossRef] [PubMed]

73. Nawaz, R.; McDonald, A.; Postoyko, S. Hydrological performance of a full-scale extensive green roof located in a temperate climate. Ecol. Eng. 2015, 82, 66-80. [CrossRef]

74. Wong, G.K.L.; Jim, C.Y. Quantitative hydrologic performance of extensive green roof under humid-tropical rainfall regime. Ecol. Eng. 2014, 70, 366-378. [CrossRef]

75. Hakimdavar, R.; Culligan, P.J.; Finazzi, M.; Barontini, S.; Ranzi, R. Scale dynamics of extensive green roofs: Quantifying the effect of drainage area and rainfall characteristics on observed and modeled green roof hydrologic performance. Ecol. Eng. 2014, 73, 494-508. [CrossRef]

76. Escobar, N.O.; Torres, A. Hydric Attenuation and Hydrological Benefits for Implementing Productive Green Roof in Soacha, Colombia. Ing. Univ. 2014, 18, 291. [CrossRef]

77. Locatelli, L.; Mark, O.; Mikkelsen, P.S.; Arnbjerg-Nielsen, K.; Jensen, M.B.; Binning, P.J. Modelling of green roof hydrological performance for urban drainage applications. J. Hydrol. 2014, 519, 3237-3248. [CrossRef]

78. Lee, J.Y.; Moon, H.J.; Kim, T.I.; Kim, H.W.; Han, M.Y. Quantitative analysis on the urban flood mitigation effect by the extensive green roof system. Environ. Pollut. 2013, 181, 257-261. [CrossRef] [PubMed]

79. Ekşi, M. A field study to evaluate the runoff quantity and stormwater retention of a typical extensive green roof in bahçeköy, Istanbul. Environ. Prot. Eng. 2013, 39, 79-89. [CrossRef]

80. Rosatto, H.; Meyer, M.; Laureda, D.; Cazorla, L.; Barrera, D.; Gamboa, P.; Villalba, G.; Bargiela, M.; Pruzzo, L.; Plaza, L.R.; et al. Water retention efficiency of green roof systems in "extensive" and "intensive" type covers. Rev. Fac. Cienc. Agrar. 2013, 45, 169-183.

81. Speak, A.F.; Rothwell, J.J.; Lindley, S.J.; Smith, C.L. Rainwater runoff retention on an aged intensive green roof. Sci. Total Environ. 2013, 461, 28-38. [CrossRef]

82. Carson, T.B.; Marasco, D.E.; Culligan, P.J.; McGillis, W.R. Hydrological performance of extensive green roofs in New York City: Observations and multi-year modeling of three full-scale systems. Environ. Res. Lett. 2013, 8, 024036. [CrossRef]

83. Burszta-Adamiak, E. Analysis of Stormwater Retention on Green Roofs/Badania Retencji Wód Opadowych Na Dachach Zielonych. Arch. Environ. Prot. 2012, 38, 3-13. [CrossRef]

84. Buccola, N.; Spolek, G. A Pilot-Scale Evaluation of Greenroof Runoff Retention, Detention, and Quality Water. Air Soil Pollut. 2011, 216, 83-92. [CrossRef]

85. Versini, P.-A.; Ramier, D.; Berthier, E.; de Gouvello, B. Assessment of the hydrological impacts of green roof: From building scale to basin scale. J. Hydrol. 2015, 524, 562-575. [CrossRef]

86. Versini, P.-A.; Gires, A.; Tchinguirinskaia, I.; Schertzer, D. Toward an operational tool to simulate green roof hydrological impact at the basin scale: A new version of the distributed rainfall-runoff model Multi-Hydro. Water Sci. Technol. 2016, 74, 1845-1854. [CrossRef]

87. Schmitter, P.; Goedbloed, A.; Galelli, S.; Babovic, V. Effect of Catchment-Scale Green Roof Deployment on Stormwater Generation and Reuse in a Tropical City. J. Water Resour. Plan. Manag. 2016, 142, 05016002. [CrossRef]

88. Mora-Melià, D.; López-Aburto, C.; Ballesteros-Pérez, P.; Muñoz-Velasco, P. Viability of Green Roofs as a Flood Mitigation Element in the Central Region of Chile. Sustainability 2018, 10, 1130. [CrossRef]

89. Ercolani, G.; Chiaradia, E.A.; Gandolfi, C.; Castelli, F.; Masseroni, D. Evaluating performances of green roofs for stormwater runoff mitigation in a high flood risk urban catchment. J. Hydrol. 2018, 566, 830-845. [CrossRef]

90. Liu, C.; Li, Y.; Li, J. Geographic information system-based assessment of mitigating flash-flood disaster from green roof systems. Comput. Environ. Urban Syst. 2017, 64, 321-331. [CrossRef]

91. Qianqian, Z.; Liping, M.; Huiwei, W.; Long, W. Analysis of the effect of green roof substrate amended with biochar on water quality and quantity of rainfall runoff. Environ. Monit. Assess. 2019, 191, 304. [CrossRef]

92. Berndtsson, J.C. Green roof performance towards management of runoff water quantity and quality: A review. Ecol. Eng. 2010, 36, 351-360. [CrossRef]

93. Chai, H.; Tang, Y.; Su, X.; Wang, W.; Lu, H.; Shao, Z.; He, Q. Annual variation patterns of the effluent water quality from a green roof and the overall impacts of its structure. Environ. Sci. Pollut. Res. 2018, 25, 30170-30179. [CrossRef]

94. Kuoppamäki, K.; Hagner, M.; Lehvävirta, S.; Setälä, H. Biochar amendment in the green roof substrate affects runoff quality and quantity. Ecol. Eng. 2016, 88, 1-9. [CrossRef]

95. Speak, A.F.; Rothwell, J.J.; Lindley, S.J.; Smith, C.L. Metal and nutrient dynamics on an aged intensive green roof. Environ. Pollut. 2014, 184, 33-43. [CrossRef] 
96. Gong, Y.; Yin, D.; Li, J.; Zhang, X.; Wang, W.; Fang, X.; Shi, H.; Wang, Q. Performance assessment of extensive green roof runoff flow and quality control capacity based on pilot experiments. Sci. Total Environ. 2019, 687, 505-515. [CrossRef]

97. Todorov, D.; Driscoll, C.T.; Todorova, S.; Montesdeoca, M. Water quality function of an extensive vegetated roof. Sci. Total Environ. 2018, 625, 928-939. [CrossRef]

98. Vijayaraghavan, K.; Joshi, U.M.; Balasubramanian, R. A field study to evaluate runoff quality from green roofs. Water Res. 2012, 46, 1337-1345. [CrossRef]

99. Whittinghill, L.J.; Rowe, D.B.; Andresen, J.A.; Cregg, B.M. Comparison of stormwater runoff from sedum, native prairie, and vegetable producing green roofs. Urban Ecosyst. 2015, 18, 13-29. [CrossRef]

100. Whittinghill, L.J.; Hsueh, D.; Culligan, P.; Plunz, R. Stormwater performance of a full scale rooftop farm: Runoff water quality. Ecol. Eng. 2016, 91, 195-206. [CrossRef]

101. Razzaghmanesh, M.; Beecham, S.; Kazemi, F. Impact of green roofs on stormwater quality in a South Australian urban environment. Sci. Total Environ. 2014, 470-471, 651-659. [CrossRef]

102. Chen, C.-F.; Kang, S.-F. Effects of substrates and plant species on water quality of extensive green roofs. Appl. Ecol. Environ. Res. 2016, 14, 77-91. [CrossRef]

103. Beecham, S.; Razzaghmanesh, M. Water quality and quantity investigation of green roofs in a dry climate. Water Res. 2015, 70, 370-384. [CrossRef]

104. Gregoire, B.G.; Clausen, J.C. Effect of a modular extensive green roof on stormwater runoff and water quality. Ecol. Eng. 2011, 37, 963-969. [CrossRef]

105. Gnecco, I.; Palla, A.; Lanza, L.G.; la Barbera, P. The Role of Green Roofs as a Source/sink of Pollutants in Storm Water Outflows. Water Resour. Manag. 2013, 27, 4715-4730. [CrossRef]

106. Kuoppamäki, K.; Lehvävirta, S. Mitigating nutrient leaching from green roofs with biochar. Landsc. Urban Plan. 2016, 152, 39-48. [CrossRef]

107. Okita, J.; Poor, C.; Kleiss, J.M.; Eckmann, T. Effect of green roof age on runoff water quality in Portland, Oregon. J. Green Build. 2018, 13, 42-54. [CrossRef]

108. Karczmarczyk, A.; Bus, A.; Baryla, A. Phosphate Leaching from Green Roof Substrates-Can Green Roofs Pollute Urban Water Bodies? Water 2018, 10, 199. [CrossRef]

109. Alsup, S.; Ebbs, S.; Battaglia, L.; Retzlaff, W. Green Roof Systems as Sources or Sinks Influencing Heavy Metal Concentrations in Runoff. J. Environ. Eng. 2013, 139, 502-508. [CrossRef]

110. Schwager, J.; Schaal, L.; Simonnot, M.-O.; Claverie, R.; Ruban, V.; Morel, J.-L. Emission of trace elements and retention of Cu and Zn by mineral and organic materials used in green roofs. J. Soils Sediments 2015, 15, 1789-1801. [CrossRef]

111. Razzaghmanesh, M.; Beecham, S.; Salemi, T. The role of green roofs in mitigating Urban Heat Island effects in the metropolitan area of Adelaide, South Australia. Urban For. Urban Green. 2016, 15, 89-102. [CrossRef]

112. Peng, L.L.H.; Yang, X.; He, Y.; Hu, Z.; Xu, T.; Jiang, Z.; Yao, L. Thermal and energy performance of two distinct green roofs: Temporal pattern and underlying factors in a subtropical climate. Energy Build. 2019, 185, 247-258. [CrossRef]

113. Lin, B.-S.; Yu, C.-C.; Su, A.-T.; Lin, Y.-J. Impact of climatic conditions on the thermal effectiveness of an extensive green roof. Build. Environ. 2013, 67, 26-33. [CrossRef]

114. Gagliano, A.; Detommaso, M.; Nocera, F.; Berardi, U. The adoption of green roofs for the retrofitting of existing buildings in the Mediterranean climate. Int. J. Sustain. Build. Technol. Urban Dev. 2016, 7, 116-129. [CrossRef]

115. Karachaliou, P.; Santamouris, M.; Pangalou, H. Experimental and numerical analysis of the energy performance of a large scale intensive green roof system installed on an office building in Athens. Energy Build. 2016, 114, 256-264. [CrossRef]

116. He, Y.; Yu, H.; Dong, N.; Ye, H. Thermal and energy performance assessment of extensive green roof in summer: A case study of a lightweight building in Shanghai. Energy Build. 2016, 127, 762-773. [CrossRef]

117. Dvorak, B.; Volder, A. Rooftop temperature reduction from unirrigated modular green roofs in south-central Texas. Urban For. Urban Green. 2013, 12, 28-35. [CrossRef]

118. Fitchett, A.; Govender, P.; Vallabh, P. An exploration of green roofs for indoor and exterior temperature regulation in the South African interior. Environ. Dev. Sustain. 2019, 22, 5025-5044. [CrossRef]

119. Hirano, Y.; Ihara, T.; Gomi, K.; Fujita, T. Simulation-Based Evaluation of the Effect of Green Roofs in Office Building Districts on Mitigating the Urban Heat Island Effect and Reducing $\mathrm{CO}_{2}$ Emissions. Sustainability 2019, 11, 2055. [CrossRef]

120. Lee, L.S.H.; Jim, C.Y. Urban woodland on intensive green roof improved outdoor thermal comfort in subtropical summer. Int. J. Biometeorol. 2019, 63, 895-909. [CrossRef] [PubMed]

121. Bevilacqua, P.; Mazzeo, D.; Bruno, R.; Arcuri, N. Surface temperature analysis of an extensive green roof for the mitigation of urban heat island in southern mediterranean climate. Energy Build. 2017, 150, 318-327. [CrossRef]

122. Alvizuri, J.; Cataldo, J.; Smalls-Mantey, L.A.; Montalto, F.A. Green roof thermal buffering: Insights derived from fixed and portable monitoring equipment. Energy Build. 2017, 151, 455-468. [CrossRef]

123. Foustalieraki, M.; Assimakopoulos, M.N.; Santamouris, M.; Pangalou, H. Energy performance of a medium scale green roof system installed on a commercial building using numerical and experimental data recorded during the cold period of the year. Energy Build. 2017, 135, 33-38. [CrossRef]

124. Gagliano, A.; Nocera, F.; Detommaso, M.; Evola, G. Thermal Behavior of an Extensive Green Roof: Numerical Simulations and Experimental Investigations. Int. J. Heat Technol. 2016, 34, S226-S234. [CrossRef] 
125. Wilkinson, S.; Feitosa, R. Retrofitting Housing with Lightweight Green Roof Technology in Sydney, Australia, and Rio de Janeiro, Brazil. Sustainability 2015, 7, 1081-1098. [CrossRef]

126. Theodosiou, T.; Aravantinos, D.; Tsikaloudaki, K. Thermal behaviour of a green vs. a conventional roof under Mediterranean climate conditions. Int. J. Sustain. Energy 2014, 33, 227-241. [CrossRef]

127. Liang, H.-H.; Huang, K.-T. Study on rooftop outdoor thermal environment and slab insulation performance of grass planted roof. Int. J. Phys. Sci. 2011, 6, 65-73.

128. Berardi, U. The outdoor microclimate benefits and energy saving resulting from green roofs retrofits. Energy Build. 2016, 121, 217-229. [CrossRef]

129. Kotsiris, G.; Androutsopoulos, A.; Polychroni, E.; Souliotis, M.; Kavga, A. Carbon footprint of green roof installation on school buildings in Greek Mediterranean climatic region. Int. J. Sustain. Energy 2019, 38, 866-883. [CrossRef]

130. Dordević, K.T.; Joksimović, O.D.; Jovanović-Popović, M.D. Energy consumption and $\mathrm{CO}_{2}$ emission reductions trough refurbishment of residential buildings' roofs by applying the Green Roof System. Therm. Sci. 2018, 22, 1217-1229. [CrossRef]

131. Pandey, S.; Hindoliya, D.A.; Mod, R. Experimental investigation on green roofs over buildings. Int. J. Low-Carbon Technol. 2013, 8 , 37-42. [CrossRef]

132. Park, J.; Kim, J.-H.; Dvorak, B.; Lee, D.K. The Role of Green Roofs on Microclimate Mitigation Effect to Local Climates in Summer. Int. J. Environ. Res. 2018, 12, 671-679. [CrossRef]

133. Heidarinejad, G.; Esmaili, A. Numerical simulation of the dual effect of green roof thermal performance. Energy Convers. Manag. 2015, 106, 1418-1425. [CrossRef]

134. Speak, A.F.; Rothwell, J.J.; Lindley, S.J.; Smith, C.L. Reduction of the urban cooling effects of an intensive green roof due to vegetation damage. Urban Clim. 2013, 3, 40-55. [CrossRef]

135. Solcerova, A.; van de Ven, F.; Wang, M.; Rijsdijk, M.; van de Giesen, N. Do green roofs cool the air? Build. Environ. 2017, 111, 249-255. [CrossRef]

136. Köhler, M.; Kaiser, D. Evidence of the Climate Mitigation Effect of Green Roofs-A 20-Year Weather Study on an Extensive Green Roof (EGR) in Northeast Germany. Buildings 2019, 9, 157. [CrossRef]

137. Lalošević, M.D.; Komatina, M.S.; Miloš, M.V.; Rudonja, N.R. Green roofs and cool materials as retrofitting strategies for urban heat Island mitigation-Case study in Belgrade, Serbia. Therm. Sci. 2018, 22, 2309-2324. [CrossRef]

138. Sisco, L.; Monzer, S.; Farajalla, N.; Bashour, I.; Saoud, I.P. Roof top gardens as a means to use recycled waste and A/C condensate and reduce temperature variation in buildings. Build. Environ. 2017, 117, 127-134. [CrossRef]

139. Mirnezhad, M.; Aminudin, A.M.R.B.; Yeap, K.S. Thermal performance and temperature mitigation towards application of green roof in tropical climate. Chem. Eng. Trans. 2017, 56, 397-402. [CrossRef]

140. Ebrahimnejad, R.; Noori, O.; Deihimfard, R. Mitigation potential of green structures on local urban microclimate using ENVI-met model. Int. J. Urban Sustain. Dev. 2017, 9, 274-285. [CrossRef]

141. Sun, T.; Grimmond, C.S.B.; Ni, G.-H. How do green roofs mitigate urban thermal stress under heat waves? J. Geophys. Res. Atmos. 2016, 121, 5320-5335. [CrossRef]

142. Klein, P.M.; Coffman, R. Establishment and performance of an experimental green roof under extreme climatic conditions. Sci. Total Environ. 2015, 512-513, 82-93. [CrossRef]

143. Hawkins, T.W. Assessing the impact of green roofs on urban heat island mitigation: A hardware scale modeling approach. Geogr. Bull. Gamma Theta Upsilon 2011, 52, 52-61.

144. Scharf, B.; Kraus, F. Green Roofs and Greenpass. Buildings 2019, 9, 205. [CrossRef]

145. Al Jadaa, D.; Raed, A.A.; Taleb, H. Assessing the thermal effectiveness of implementing green roofs in the urban neighborhood, Jordan. J. Mech. Ind. Eng. 2019, 13, 161-174.

146. Peng, L.L.H.; Jim, C.Y. Green-Roof Effects on Neighborhood Microclimate and Human Thermal Sensation. Energies 2013, 6, 598-618. [CrossRef]

147. Moghbel, M.; Salim, R.E. Environmental benefits of green roofs on microclimate of Tehran with specific focus on air temperature, humidity and $\mathrm{CO}_{2}$ content. Urban Clim. 2017, 20, 46-58. [CrossRef]

148. Agra, H.; Klein, T.; Vasl, A.; Shalom, H.; Kadas, G.; Blaustein, L. Sedum-dominated green-roofs in a semi-arid region increase $\mathrm{CO}_{2}$ concentrations during the dry season. Sci. Total Environ. 2017, 584-585, 1147-1151. [CrossRef]

149. Tong, Z.; Whitlow, T.H.; Landers, A.; Flanner, B. A case study of air quality above an urban roof top vegetable farm. Environ. Pollut. 2016, 208, 256-260. [CrossRef] [PubMed]

150. Speak, A.F.; Rothwell, J.J.; Lindley, S.J.; Smith, C.L. Urban particulate pollution reduction by four species of green roof vegetation in a UK city. Atmos. Environ. 2012, 61, 283-293. [CrossRef]

151. Morales, W.V.; Jazcilevich, A.; Reynoso, A.G.; Caetano, E.; Gómez, G.; Bornstein, R.D. Influence of Green Roofs on Early Morning Mixing Layer Depths in Mexico City. J. Sol. Energy Eng. 2016, 138. [CrossRef]

152. Ramasubramanian, P.; Starry, O.; Rosenstiel, T.; Gall, E.T. Pilot study on the impact of green roofs on ozone levels near building ventilation air supply. Build. Environ. 2019, 151, 43-53. [CrossRef]

153. Moradpour, M.; Afshin, H.; Farhanieh, B. A numerical study of reactive pollutant dispersion in street canyons with green roofs. Build. Simul. 2018, 11, 125-138. [CrossRef]

154. Park, S.-J.; Choi, W.; Kim, J.-J.; Kim, M.J.; Park, R.J.; Han, K.-S.; Kang, G. Effects of building-roof cooling on the flow and dispersion of reactive pollutants in an idealized urban street canyon. Build. Environ. 2016, 109, 175-189. [CrossRef] 
155. Baik, J.J.; Kwak, K.H.; Park, S.B.; Ryu, Y.H. Effects of building roof greening on air quality in street canyons. Atmos. Environ. 2012, 61, 48-55. [CrossRef]

156. Nadal, A.; Cerón-Palma, I.; García-Gómez, C.; Pérez-Sánchez, M.; Rodríguez-Labajos, B.; Cuerva, E.; Josa, A.; Rieradevall, J. Social perception of urban agriculture in Latin-America. A case study in Mexican social housing. Land Use Policy 2018, 76, 719-734. [CrossRef]

157. Kim, E.; Jung, J.; Hapsari, G.; Kang, S.; Kim, K.; Yoon, S.; Lee, M.; Han, M.; Choi, Y.; Choe, J.K. Economic and environmental sustainability and public perceptions of rooftop farm versus extensive garden. Build. Environ. 2018, 146, 206-215. [CrossRef]

158. Tabatabaee, S.; Mahdiyar, A.; Durdyev, S.; Mohandes, S.R.; Ismail, S. An assessment model of benefits, opportunities, costs, and risks of green roof installation: A multi criteria decision making approach. J. Clean. Prod. 2019, 238, 117956. [CrossRef]

159. Tam, V.W.Y.; Wang, J.; Le, K.N. Thermal insulation and cost effectiveness of green-roof systems: An empirical study in Hong Kong. Build. Environ. 2016, 110, 46-54. [CrossRef]

160. Rezvani, M.; Sanazlitkouhi, S.E.; Sheyasi, F. Investigation of role of green roofs as a strategy for improving the quality of urban environment in terms of sustainable architecture, Middle East. J. Sci. Res. 2013, 14, 992-998. [CrossRef]

161. Zhang, L.; Fukuda, H.; Liu, Z. Households' willingness to pay for green roof for mitigating heat island effects in Beijing (China). Build. Environ. 2019, 150, 13-20. [CrossRef]

162. Fernandez-Cañero, R.; Emilsson, T.; Fernandez-Barba, C.; Machuca, M.Á.H. Green roof systems: A study of public attitudes and preferences in southern Spain. J. Environ. Manag. 2013, 128, 106-115. [CrossRef] [PubMed]

163. Vanstockem, J.; Vranken, L.; Bleys, B.; Somers, B.; Hermy, M. Do Looks Matter? A Case Study on Extensive Green Roofs Using Discrete Choice Experiments. Sustainability 2018, 10, 309. [CrossRef]

164. Jungels, J.; Rakow, D.A.; Allred, S.B.; Skelly, S.M. Attitudes and aesthetic reactions toward green roofs in the Northeastern United States. Landsc. Urban Plan. 2013, 117, 13-21. [CrossRef]

165. Lee, K.E.; Williams, K.J.H.; Sargent, L.D.; Farrell, C.; Williams, N.S. Living roof preference is influenced by plant characteristics and diversity. Landsc. Urban Plan. 2015, 122, 152-159. [CrossRef]

166. Loder, A. 'There's a meadow outside my workplace': A phenomenological exploration of aesthetics and green roofs in Chicago and Toronto. Landsc. Urban Plan. 2014, 126, 94-106. [CrossRef]

167. Mesimäki, M.; Hauru, K.; Lehvävirta, S. Do small green roofs have the possibility to offer recreational and experiential benefits in a dense urban area? A case study in Helsinki, Finland. Urban For. Urban Green. 2019, 40, 114-124. [CrossRef]

168. Hossain, M.A.; Shams, S.; Amin, M.; Reza, M.S.; Chowdhury, T.U. Perception and Barriers to Implementation of Intensive and Extensive Green Roofs in Dhaka, Bangladesh. Buildings 2019, 9, 79. [CrossRef]

169. Everett, G.; Lamond, J. Green roof perceptions: Newcastle, UK CBD owners/occupiers. J. Corp. Real Estate 2019, $21,130-147$. [CrossRef]

170. Shams, S.; Ismail, P.H.R.I.B.P.; Zania, A.B.H.; Mohamad, A.B.H. Challenges and opportunities of green roof in building design: A case study in Bandar Seri Begawan. Malays. Constr. Res. J. 2018, 5, 113-123.

171. Briz-de-Felipe, T.; de Felipe-Boente, I. A methodological approach for urban green areas: A case study in Madrid. Rev. Chapingo Ser. Cienc. For. Ambient. 2017, 23, 315-328. [CrossRef]

172. Maryanti, M.R.; Ainur, Z.Z.; Tan, P.W.; Norhidayah, M.Y.; Khadijah, H.; Razali, M.N.; Maslinda, A.L. Rooftop garden development in Iskandar, Malaysia: Growth and perception. WIT Trans. Ecol. Environ. 2014, 186, 411-419. [CrossRef]

173. Teotónio, I.; Silva, C.M.; Cruz, C.O. Eco-solutions for urban environments regeneration: The economic value of green roofs. J. Clean. Prod. 2018, 199, 121-135. [CrossRef]

174. Ziogou, I.; Michopoulos, A.; Voulgari, V.; Zachariadis, T. Implementation of green roof technology in residential buildings and neighborhoods of Cyprus. Sustain. Cities Soc. 2018, 40, 233-243. [CrossRef]

175. Ziogou, I.; Michopoulos, A.; Voulgari, V.; Zachariadis, T. Energy, environmental and economic assessment of electricity savings from the operation of green roofs in urban office buildings of a warm Mediterranean region. J. Clean. Prod. 2017, 168, 346-356. [CrossRef]

176. Shin, E.; Kim, H. Analysing Green Roof Effects in an Urban Environment: A Case of Bangbae-dong, Seoul. J. Asian Archit. Build. Eng. 2015, 14, 315-322. [CrossRef]

177. Mahdiyar, A.; Tabatabaee, S.; Sadeghifam, A.N.; Mohandes, S.R.; Abdullah, A.; Meynagh, M.M. Probabilistic private cost-benefit analysis for green roof installation: A Monte Carlo simulation approach. Urban For. Urban Green 2016, 20, 317-327. [CrossRef]

178. Mullen, J.D.; Lamsal, M.; Colson, G. Green Roof Adoption in Atlanta, Georgia: The Effects of Building Characteristics and Subsidies on Net Private, Public, and Social Benefits. Environ. Sci. Technol. 2013, 47, 10824-10831. [CrossRef]

179. Shin, E.; Kim, H. Benefit-Cost Analysis of Green Roof Initiative Projects: The Case of Jung-gu, Seoul. Sustainability 2019, 11, 3319. [CrossRef]

180. Cascone, S.; Catania, F.; Gagliano, A.; Sciuto, G. A comprehensive study on green roof performance for retrofitting existing buildings. Build. Environ. 2018, 136, 227-239. [CrossRef]

181. Foudi, S.; Spadaro, J.V.; Chiabai, A.; Polanco-Martínez, J.M.; Neumann, M.B. The climatic dependencies of urban ecosystem services from green roofs: Threshold effects and non-linearity. Ecosyst. Serv. 2017, 24, 223-233. [CrossRef]

182. Mahmoud, A.; Asif, M.; Hassanain, M.; Babsail, M.; Sanni-Anibire, M. Energy and Economic Evaluation of Green Roofs for Residential Buildings in Hot-Humid Climates. Buildings 2017, 7, 30. [CrossRef] 
183. Mayrand, F.; Clergeau, P. Green Roofs and Green Walls for Biodiversity Conservation: A Contribution to Urban Connectivity? Sustainability 2018, 10, 985. [CrossRef]

184. Taleghani, M.; Kleerekoper, L.; Tenpierik, M.; van den Dobbelsteen, A. Outdoor thermal comfort within five different urban forms in the Netherlands. Build. Environ. 2015, 83, 65-78. [CrossRef]

185. Haase, D.; Kabisch, S.; Haase, A.; Andersson, E.; Banzhaf, E.; Baró, F.; Brenck, M.; Fischer, L.K.; Frantzeskaki, N.; Kabisch, N.; et al. Greening cities-To be socially inclusive? About the alleged paradox of society and ecology in cities. Habitat Int. 2017, 64, 41-48. [CrossRef] 